\title{
Aromatic dendrimers bearing 2,4,6-triphenyl-1,3,5- triazine cores and their photocatalytic performance
}

\section{Supporting Information}

Jakub S. Cyniak and Artur Kasprzak*

Faculty of Chemistry, Warsaw University of Technology, Noakowskiego Str. 3, 00-664 Warsaw, Poland

*corresponding author e-mail: akasprzak@ch.pw.edu.pl

\section{Table of CONTENTS}

S1. Optimization experiments toward the synthesis of D1 and D2 …..................S2

S2. Compounds characterization data ..................................................... 5

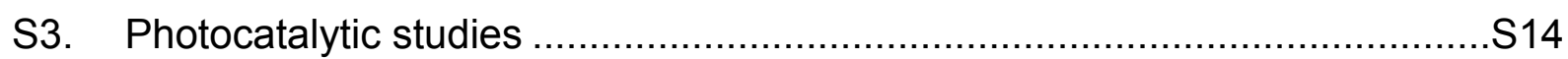

S3.1 Photocatalytic synthesis of $N$-benzylidene benzylamines from

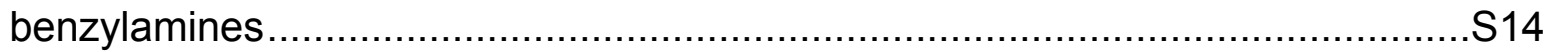

S3.2 Determination of conversion of benzylamine based on ${ }^{1} \mathrm{H}$ NMR spectra...S16

S3.3 ${ }^{1} \mathrm{H}$ NMR spectrum of the isolated $N$-benzylidene benzylamine (6) under optimized conditions S17

S34.4 Determination of HOMO-LUMO band gaps for D1 and D2 S18

S3.5 Plausible literature reaction mechanism S18

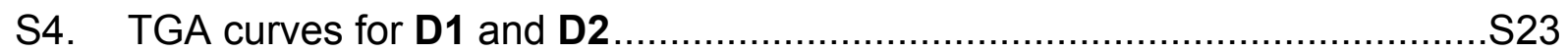

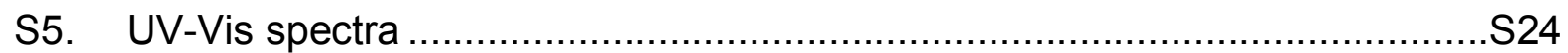

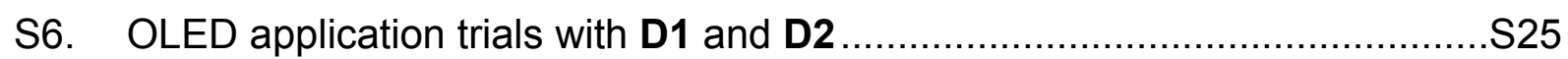

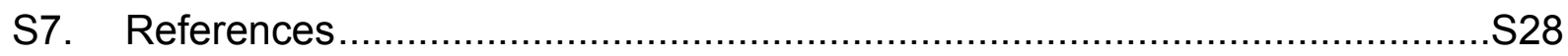


S1. Optimization experiments toward the synthesis of D1 and D2

The data for optimization experiments are summarized in Table S1 and Table S2 located below. 
Table S1. Optimization experiments for the synthesis of D1.

\begin{tabular}{|c|c|c|c|c|c|c|c|c|}
\hline Entry & $\begin{array}{c}2 \\
\text { (mg; } \\
\text { mmol; } \\
\text { equiv) }\end{array}$ & $\begin{array}{c}3 \\
\text { (mg; } \\
\text { mmol; } \\
\text { equiv) }\end{array}$ & $\begin{array}{c}\text { solvent } \\
(\mathrm{ml})\end{array}$ & $\begin{array}{c}\text { catalyst } \\
\text { (mg; mmol; } \\
\text { equiv) }\end{array}$ & $\begin{array}{c}\text { base } \\
\text { (mg; } \\
\text { mmol; } \\
\text { equiv) }\end{array}$ & $\begin{array}{c}\text { Reaction } \\
\text { time } \\
\text { (hours) }\end{array}$ & $\begin{array}{c}\text { temp. } \\
\left({ }^{\circ} \mathrm{C}\right)\end{array}$ & $\begin{array}{c}\text { D1 } \\
\text { yield }^{a} \\
\text { (mg; } \\
\%)\end{array}$ \\
\hline 1 & $\begin{array}{c}8.8 \\
0.02 \\
1.0 \\
\end{array}$ & $\begin{array}{c}21.6 \\
14.28 \\
\underline{3.5}\end{array}$ & $\begin{array}{c}\mathrm{PhMe} \\
(2.1) ; \\
\mathrm{H}_{2} \mathrm{O} \\
(0.7) ; \\
\mathrm{EtOH} \\
(0.7)\end{array}$ & $\begin{array}{c}\mathrm{Pd}\left(\mathrm{PPh}_{3}\right)_{4} \\
3.5 ; 0.003 \\
\underline{0.15}\end{array}$ & $\begin{array}{c}\mathrm{Na}_{2} \mathrm{CO}_{3} \\
21.2 ; 0.2 ; \\
\underline{10}\end{array}$ & 24 & reflux & $\begin{array}{l}4.6 ; \\
23.0\end{array}$ \\
\hline 2 & $\begin{array}{c}8.8 \\
0.02 \\
1.0 \\
\end{array}$ & $\begin{array}{c}21.6 \\
0.07 \\
\underline{3.5}\end{array}$ & $\begin{array}{l}\text { DMF } \\
(3.5)\end{array}$ & $\begin{array}{c}\mathrm{Pd}(\mathrm{dppf}) \mathrm{Cl}_{2} \\
2.2 ; 0.003 ; \\
\underline{0.15}\end{array}$ & $\begin{array}{c}\mathrm{CH}_{3} \mathrm{COOK} \\
19.6 ; 0.2 ; \\
\underline{10}\end{array}$ & 24 & reflux & $\begin{array}{l}3.4 ; \\
17.0\end{array}$ \\
\hline 3 & $\begin{array}{c}8.8 \\
0.02 \\
1.0 \\
\end{array}$ & $\begin{array}{c}21.6 \\
0.07 \\
\underline{3.5}\end{array}$ & $\begin{array}{c}\text { PhMe } \\
(2.1) ; \\
\mathrm{H}_{2} \mathrm{O} \\
(0.7) ; \\
\text { EtOH } \\
(0.7)\end{array}$ & $\begin{array}{c}\mathrm{Pd}\left(\mathrm{PPh}_{3}\right)_{4} \\
3.5 ; 0.003 \\
\underline{0.15}\end{array}$ & $\begin{array}{c}\mathrm{Na}_{2} \mathrm{CO}_{3} \\
21.2 ; 0.2 ; \\
\underline{10}\end{array}$ & 48 & reflux & $\begin{array}{l}4.1 \\
21.0\end{array}$ \\
\hline 4 & $\begin{array}{c}8.8 \\
0.02 \\
1.0 \\
\end{array}$ & $\begin{array}{c}21.6 \\
0.07 \\
\underline{3.5}\end{array}$ & $\begin{array}{c}\text { PhMe } \\
(2) ; \\
\text { EtOH } \\
(2)\end{array}$ & $\begin{array}{c}\mathrm{Pd}(\mathrm{dppf}) \mathrm{Cl}_{2} \\
2.2 ; 0.003 \\
\underline{0.15}\end{array}$ & $\begin{array}{c}\mathrm{K}_{2} \mathrm{CO}_{3} \\
33.2 ; 0.24 ; \\
\underline{12}\end{array}$ & 24 & reflux & $\begin{array}{l}4.8 \\
24.0\end{array}$ \\
\hline 5 & $\begin{array}{c}8.8 \\
0.02 \\
1.0 \\
\end{array}$ & $\begin{array}{c}21.6 \\
0.07 \\
\underline{3.5}\end{array}$ & $\begin{array}{c}\text { PhMe } \\
(2) ; \\
\text { EtOH } \\
(2)\end{array}$ & $\begin{array}{c}\text { XPhos Pd } \\
\text { G2 } \\
4.7 ; 0.005 ; \\
\underline{0.3} \\
\text { XPhos } \\
5.7 ; 0.01 \\
\underline{0.6}\end{array}$ & $\begin{array}{c}\mathrm{K}_{2} \mathrm{CO}_{3} \\
33.2 ; 0.24 ; \\
\underline{12}\end{array}$ & 24 & reflux & $\begin{array}{l}7.7 \\
39.0\end{array}$ \\
\hline 6 & $\begin{array}{c}8.8 \\
0.02 \\
1.0 \\
\end{array}$ & $\begin{array}{c}21.6 \\
0.07 \\
\underline{3.5}\end{array}$ & $\begin{array}{c}\text { PhMe } \\
(2.1) ; \\
\mathrm{H}_{2} \mathrm{O} \\
(0.7) ; \\
\text { EtOH } \\
(0.7)\end{array}$ & $\begin{array}{c}\mathrm{Pd}\left(\mathrm{PPh}_{3}\right)_{4} \\
6.9 ; 0.006 \\
\underline{0.3}\end{array}$ & $\begin{array}{c}\mathrm{K}_{2} \mathrm{CO}_{3} \\
33,2 ; 0.24 ; \\
\underline{12}\end{array}$ & 24 & reflux & $\begin{array}{l}8.9 \\
50.0\end{array}$ \\
\hline
\end{tabular}

a Isolated yield. 
Table S2. Optimization experiments for the synthesis of D2.

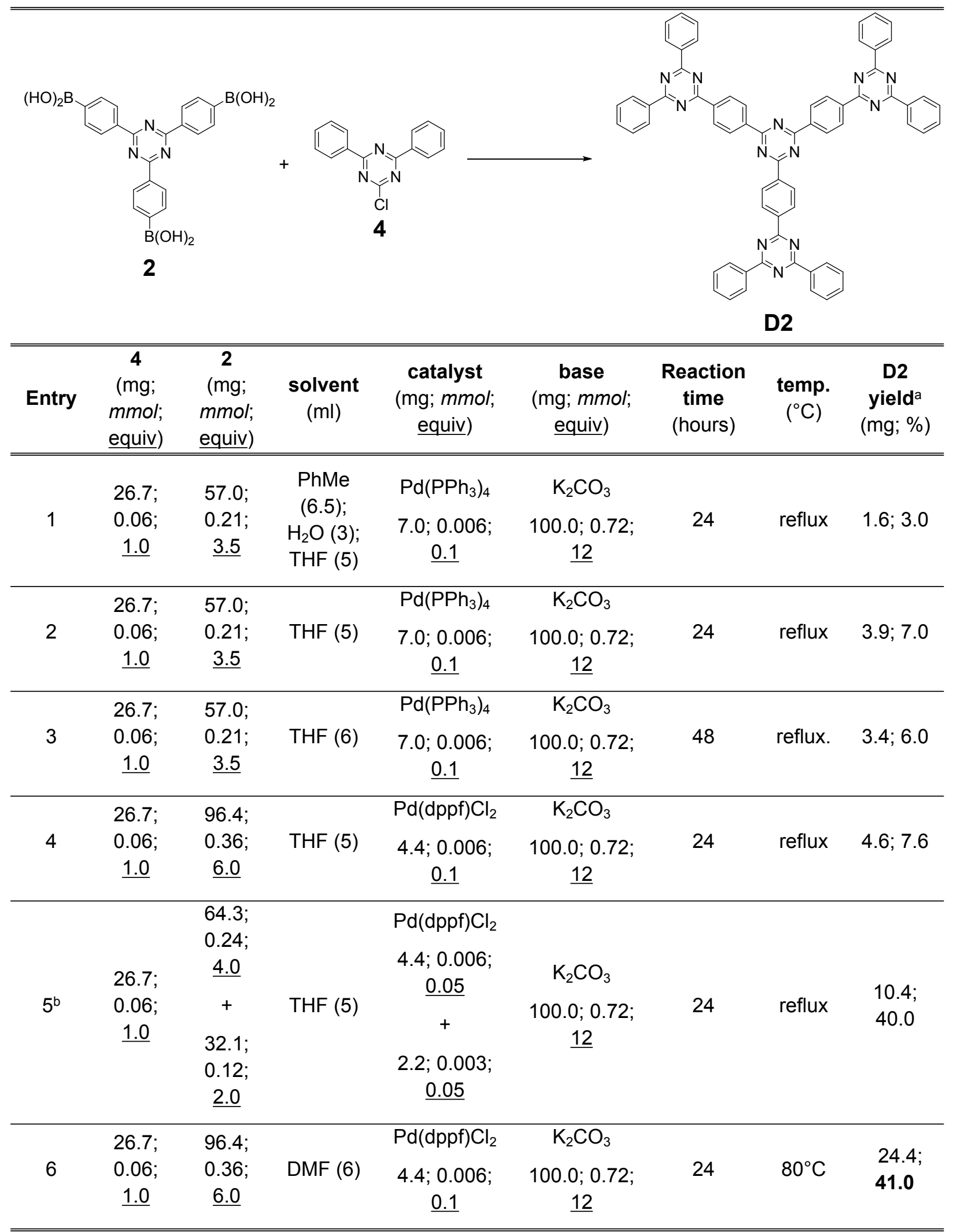

a Isolated yield; ${ }^{\mathrm{b}}$ In this trial, new portion of $\mathbf{4}$ and Pd catalyst were added after 6 hours. 


\section{S2. Compounds characterization data}

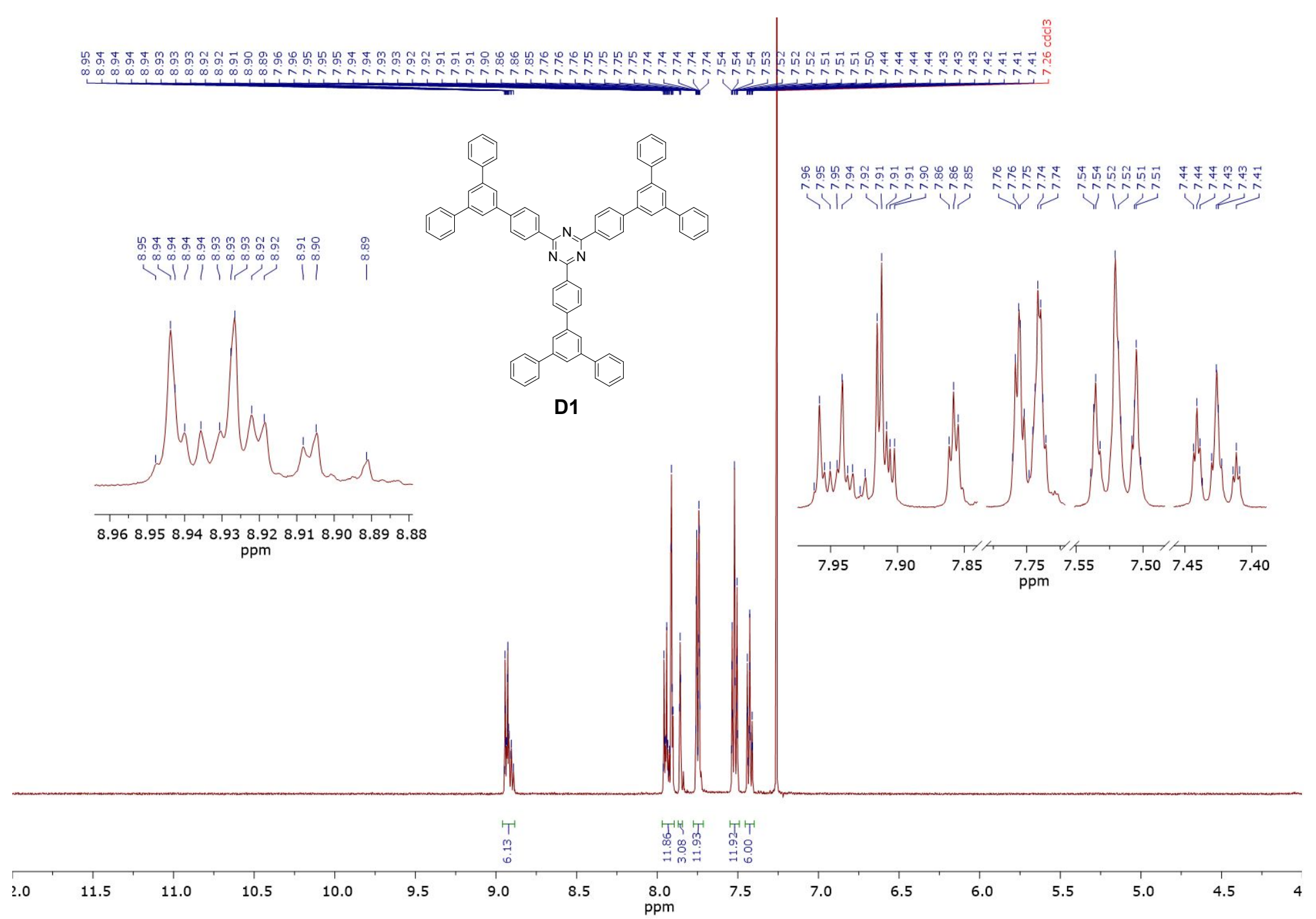

Figure S1. ${ }^{1} \mathrm{H}$ NMR spectrum $\left(500 \mathrm{MHz}, \mathrm{CDCl}_{3}\right)$ of $\mathbf{D} 1$. 


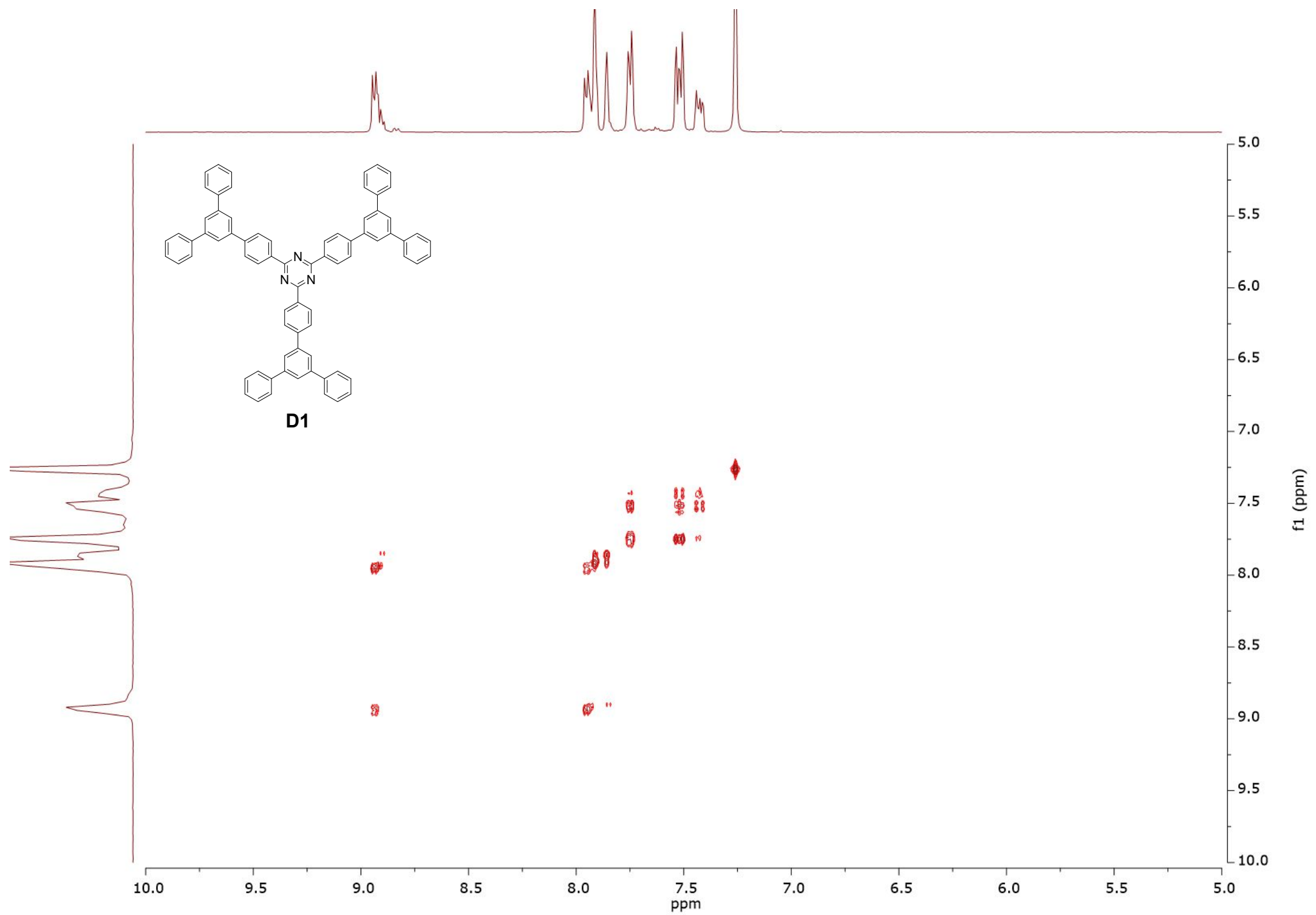

Figure S2. ${ }^{1} \mathrm{H}-{ }^{-1} \mathrm{H}$ COSY NMR spectrum $\left(500 \mathrm{MHz}, \mathrm{CDCl}_{3}\right)$ of $\mathbf{D} 1$. 


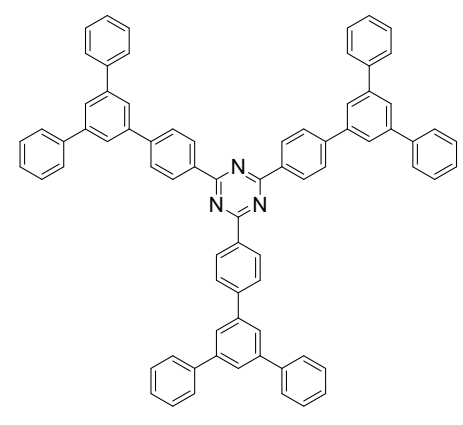

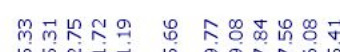

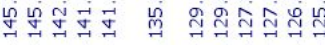

D1

पit

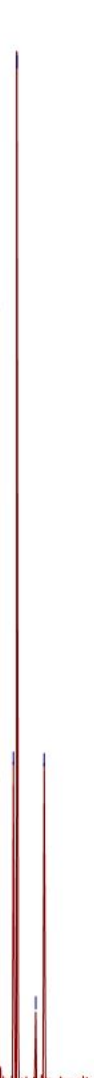

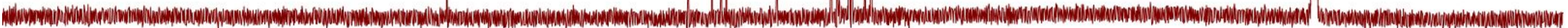

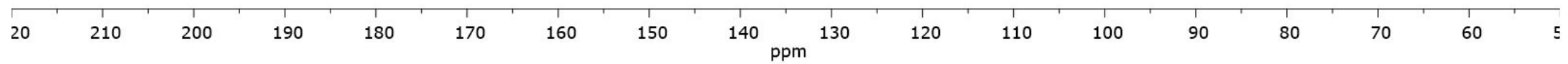

Figure S3. ${ }^{13} \mathrm{C}\left\{{ }^{1} \mathrm{H}\right\} \mathrm{NMR}$ spectrum $\left(125 \mathrm{MHz}, \mathrm{CDCl}_{3}\right)$ of $\mathbf{D} 1$. 

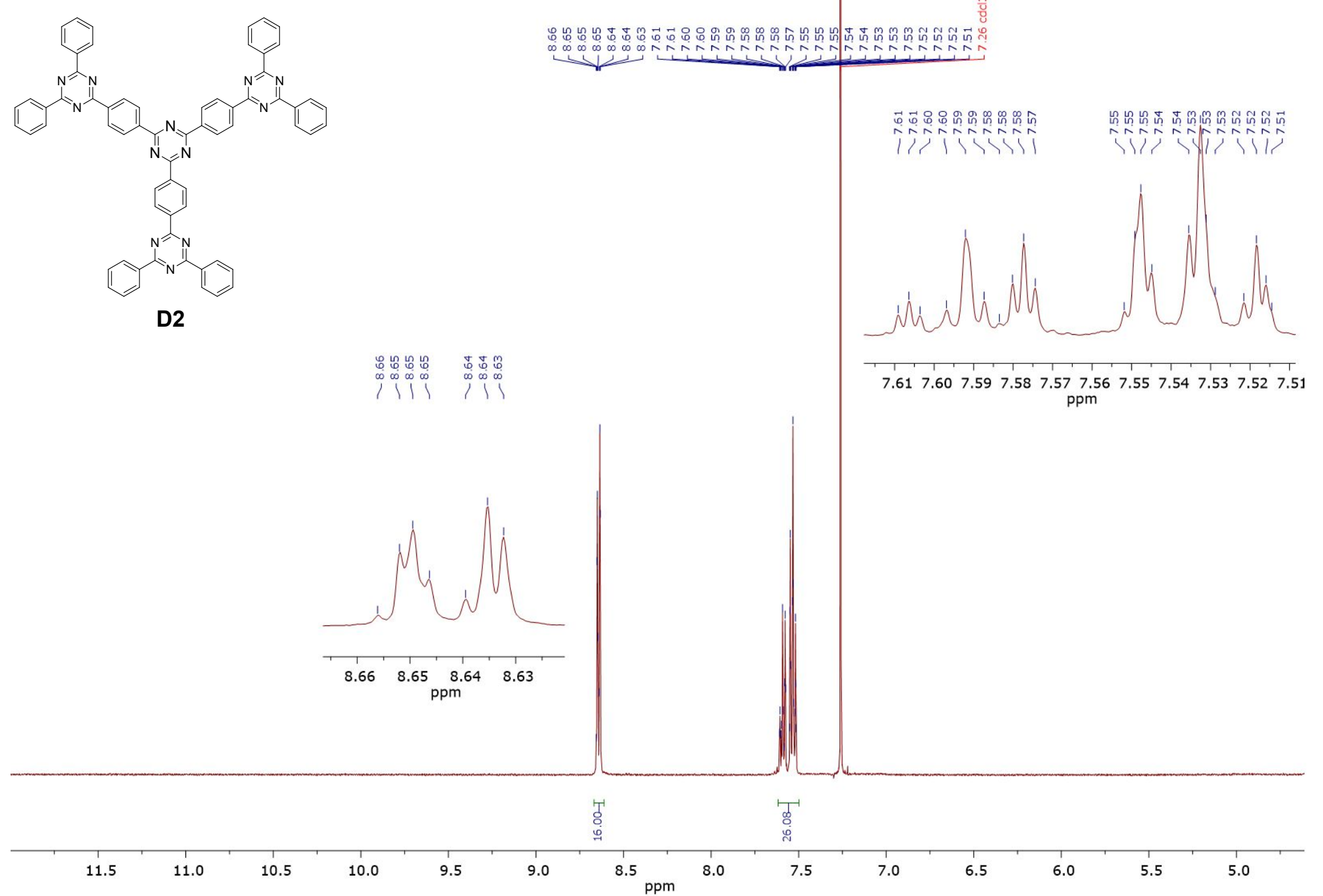

Figure S4. ${ }^{1} \mathrm{H}$ NMR spectrum $\left(500 \mathrm{MHz}, \mathrm{CDCl}_{3}\right)$ of $\mathbf{D 2}$. 


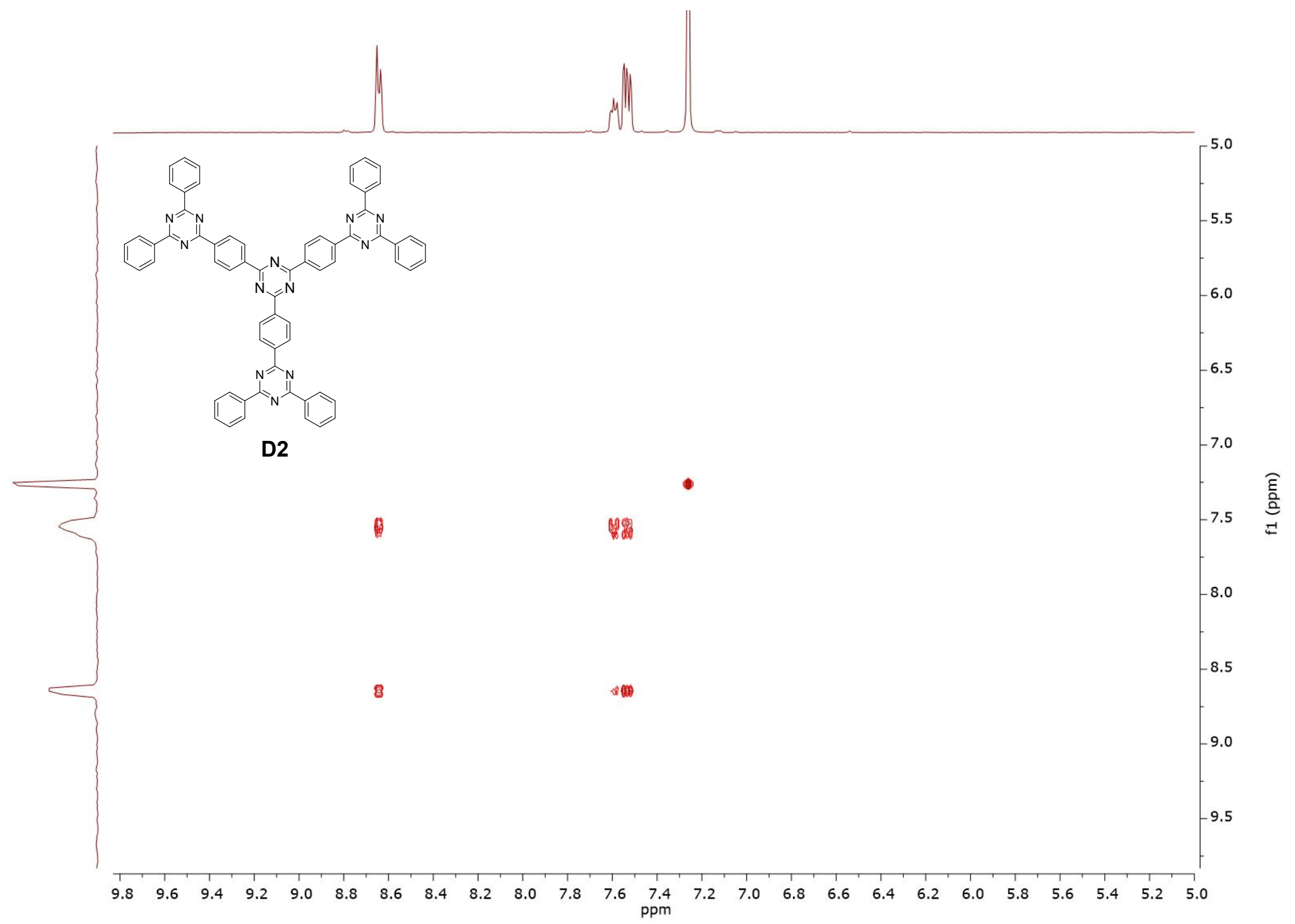

Figure S5. ${ }^{1} \mathrm{H}-{ }^{1} \mathrm{H}$ COSY NMR spectrum $\left(500 \mathrm{MHz}^{-\mathrm{CDCl}_{3}}\right.$ ) of $\mathbf{D 2}$. 

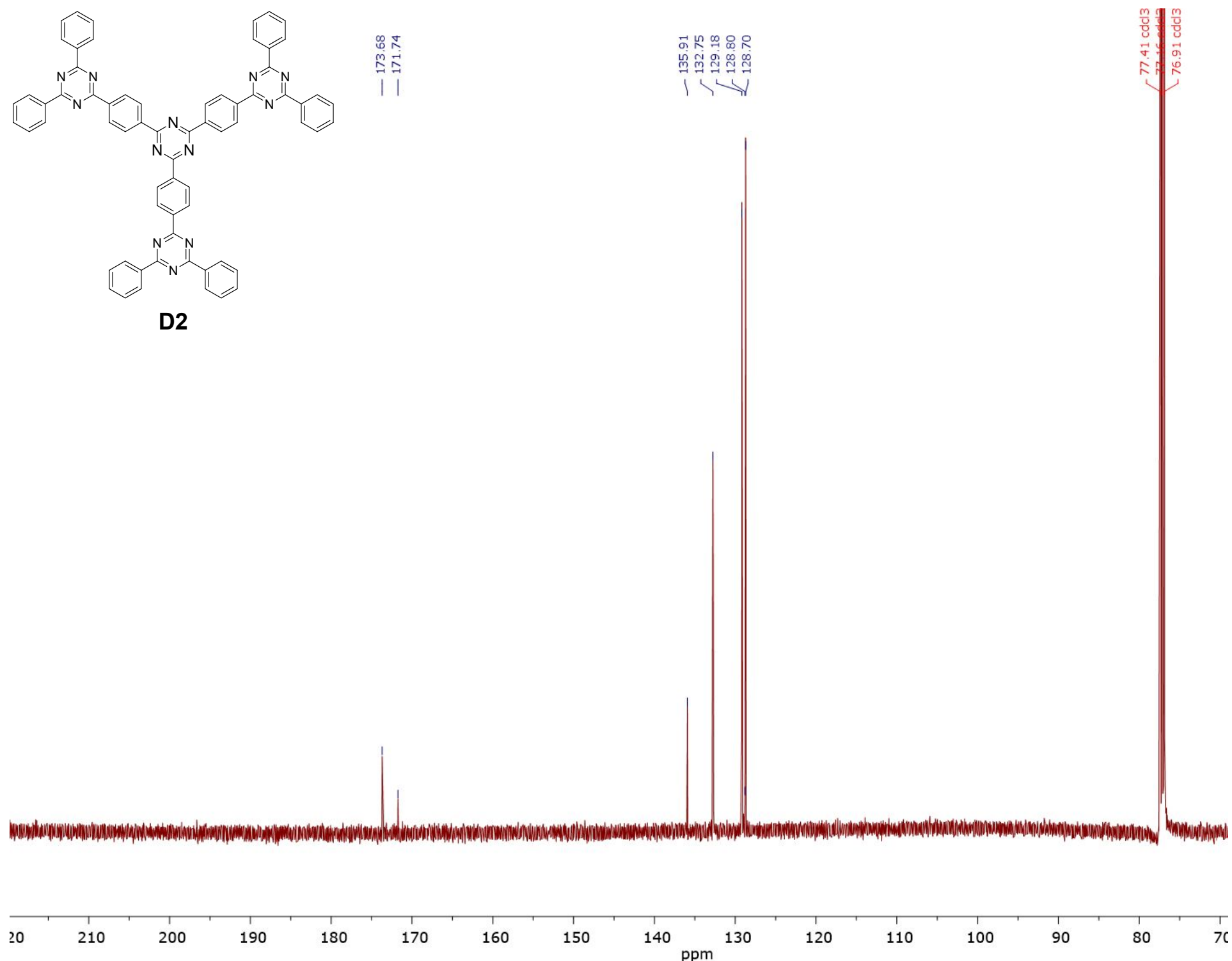

Figure S6. ${ }^{13} \mathrm{C}\left\{{ }^{1} \mathrm{H}\right\}$ NMR spectrum $\left(125 \mathrm{MHz}, \mathrm{CDCl}_{3}\right)$ of $\mathbf{D} 2$. 
a)

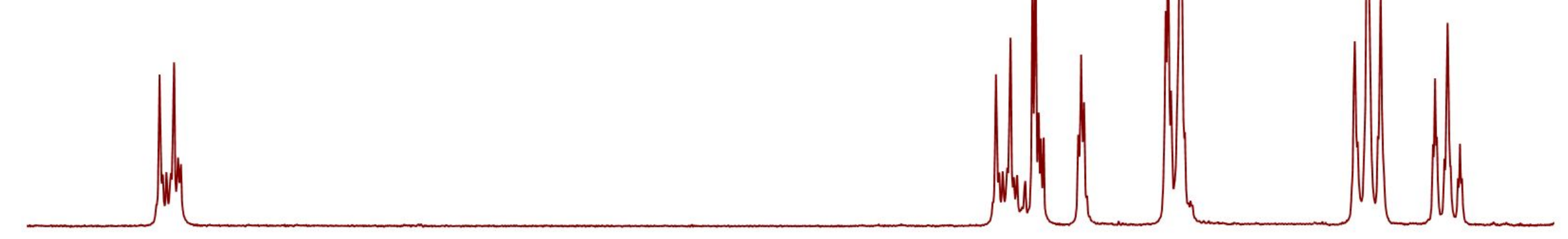

b)
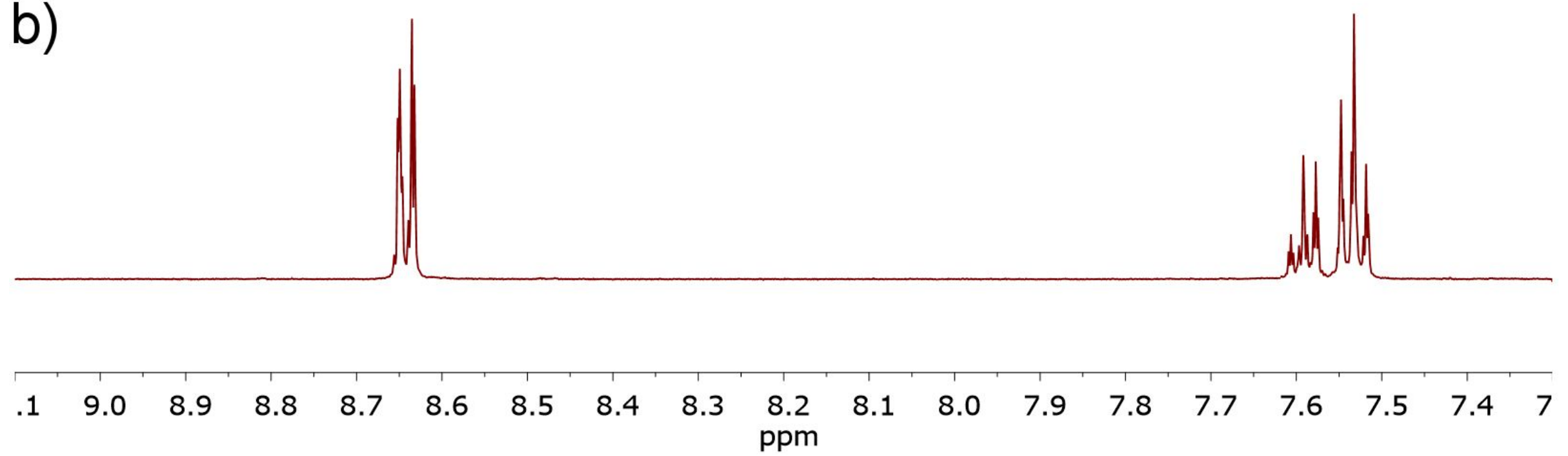

Figure S7. Comparison of ${ }^{1} \mathrm{H}$ NMR spectra (500 MHz, $\mathrm{CDCl}_{3}$ ) of $\mathbf{D} 1$ (a) and $\mathbf{D} 2$ (b). 9.10-7.30 ppm insets are presented. 


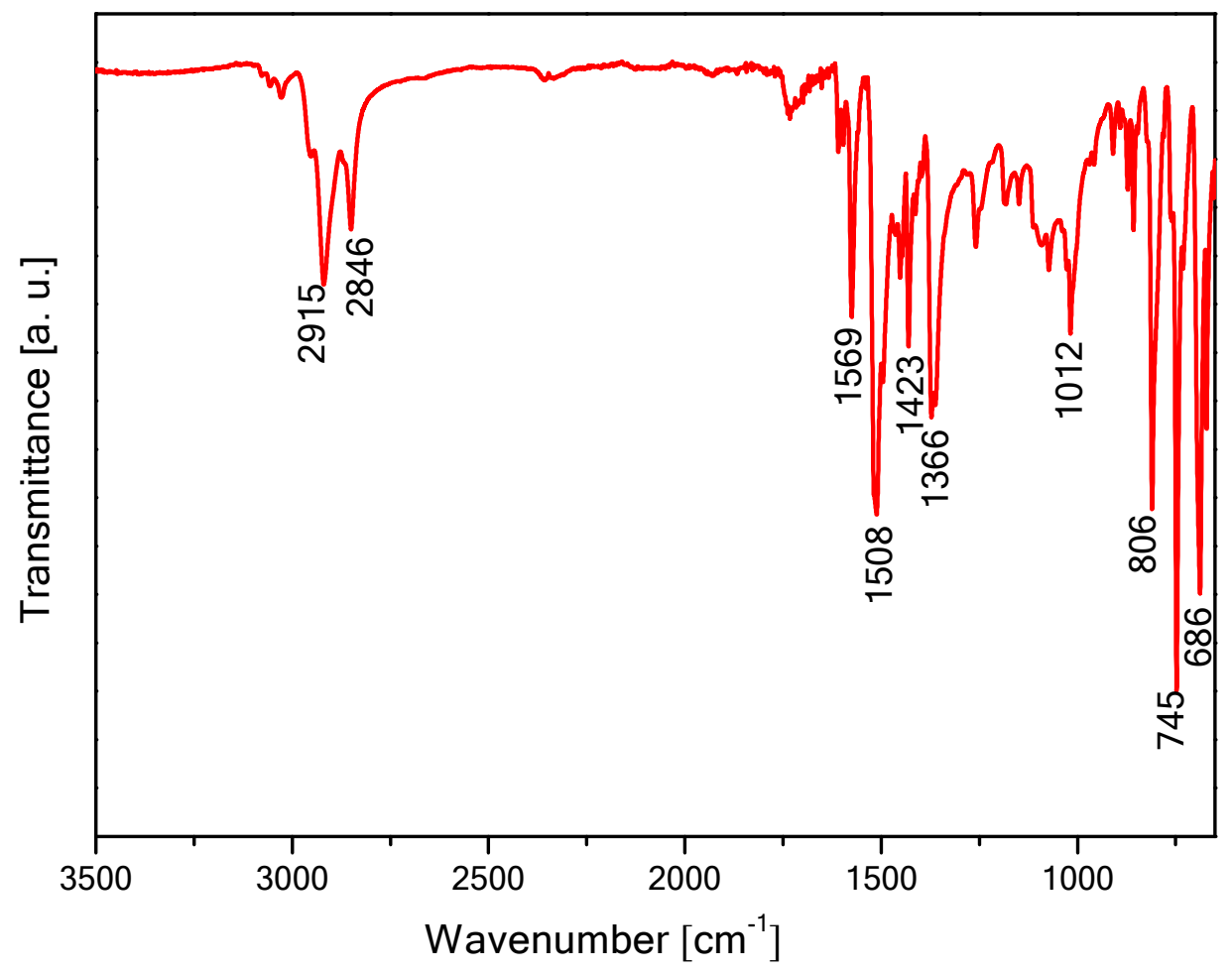

Figure S8. FT-IR spectrum of D1.

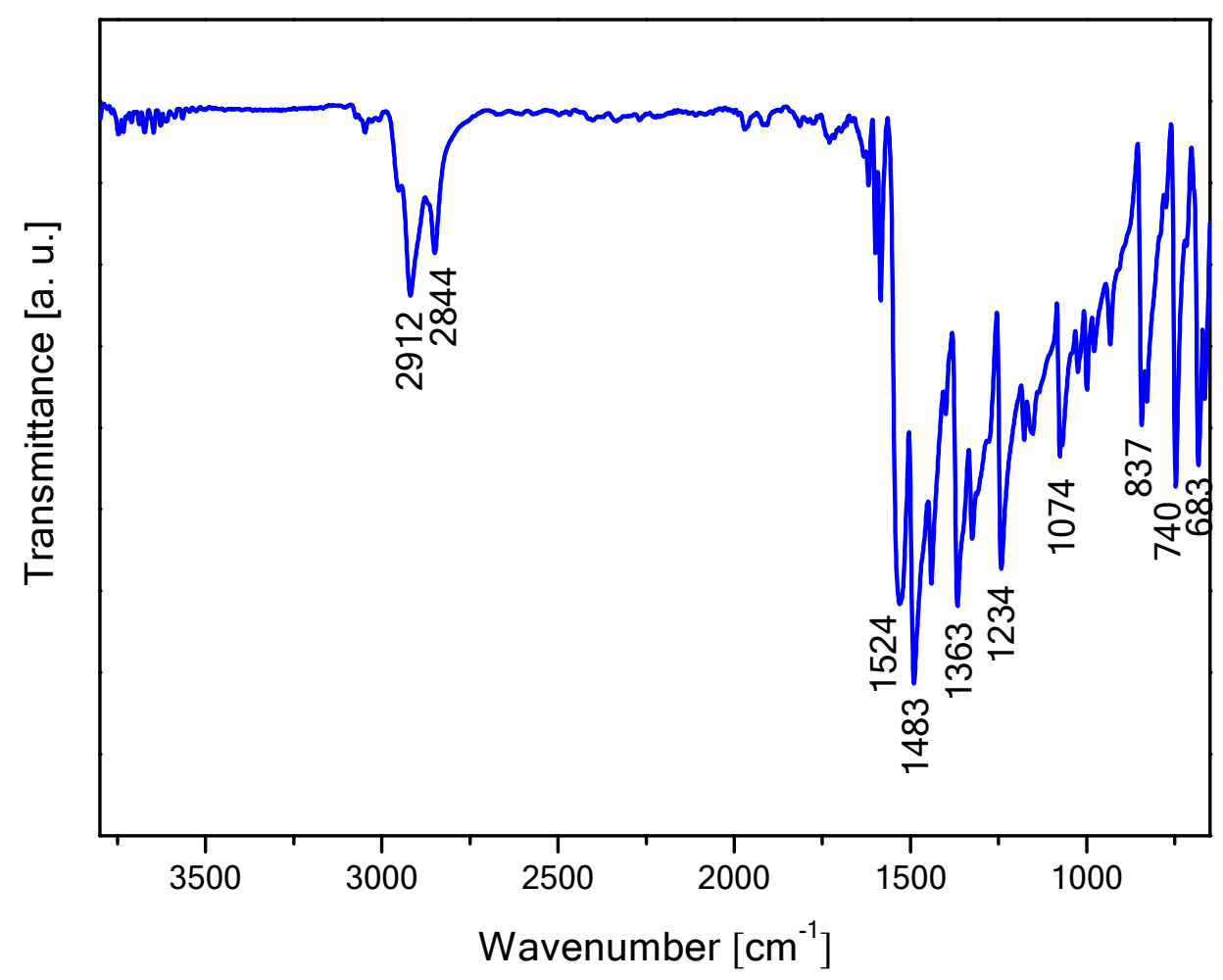

Figure S9. FT-IR spectrum of D2. 


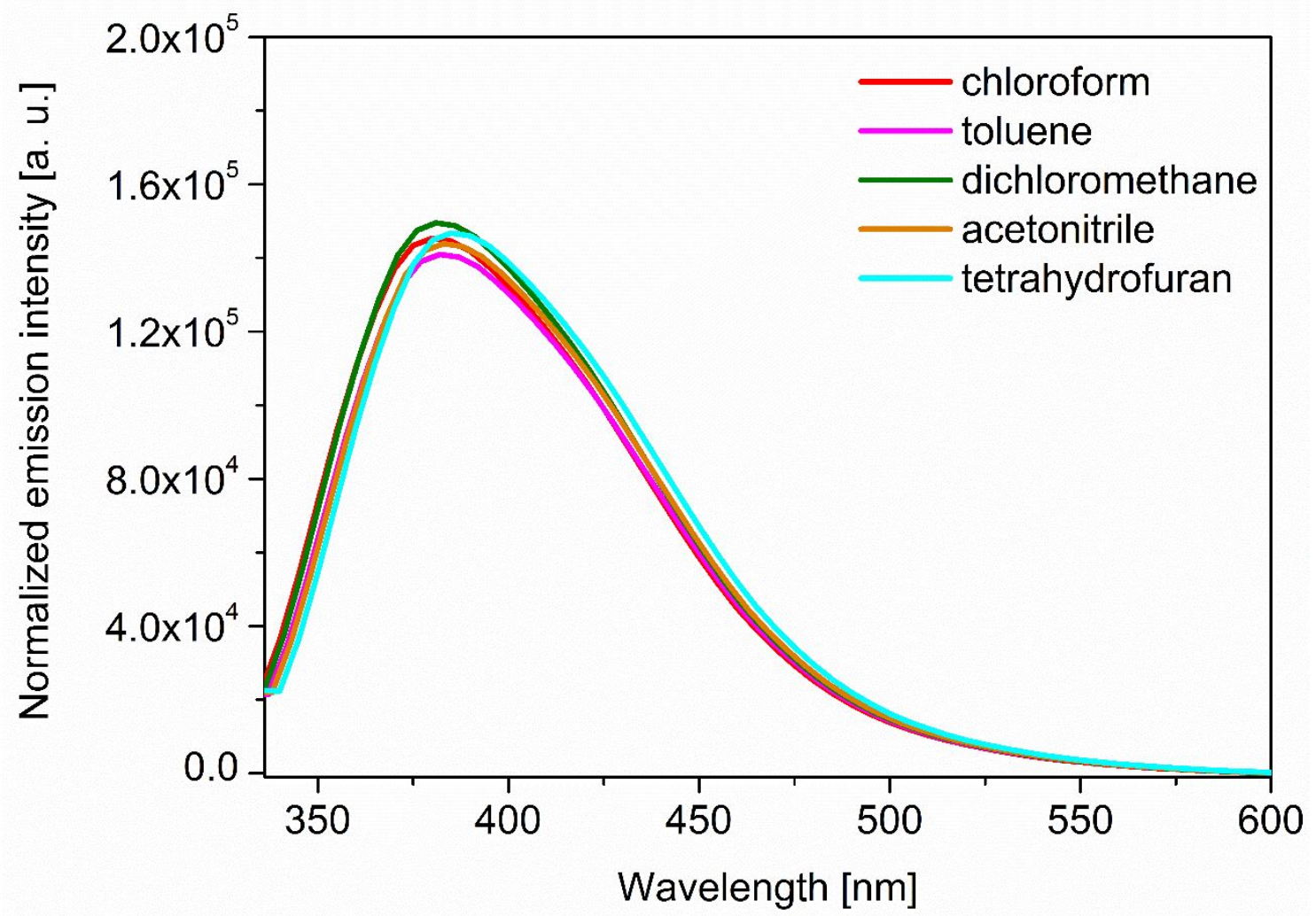

Figure S10. Emission spectra for D1 measured in different solvents. Concentrations of the samples: $2 \cdot 10^{-5} \mathrm{M} . \lambda_{\mathrm{ex}}=315 \mathrm{~nm}$.

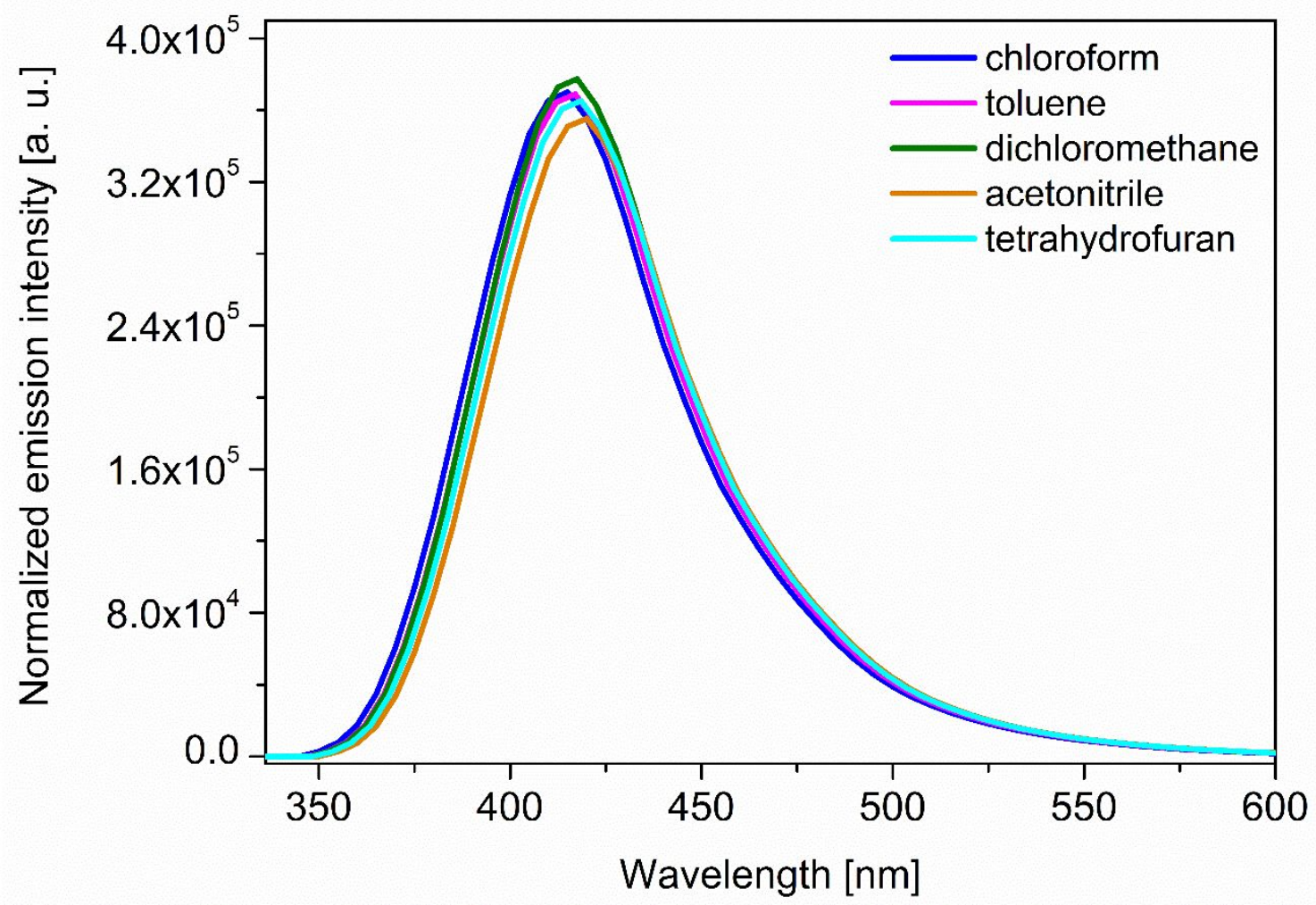

Figure S11. Emission spectra for D2 measured in different solvents. Concentrations of the samples: $2 \cdot 10^{-5} \mathrm{M}$. $\lambda_{\mathrm{ex}}=315 \mathrm{~nm}$. 


\section{S3. Photocatalytic studies}

\section{S3.1 Photocatalytic synthesis of $\mathbf{N}$-benzylidene benzylamines from benzylamines}

Table S3. The results of the optimization experiments toward photocatalytic oxidation of benzylamine (6) using D1 or D2 as the photocatalyst.

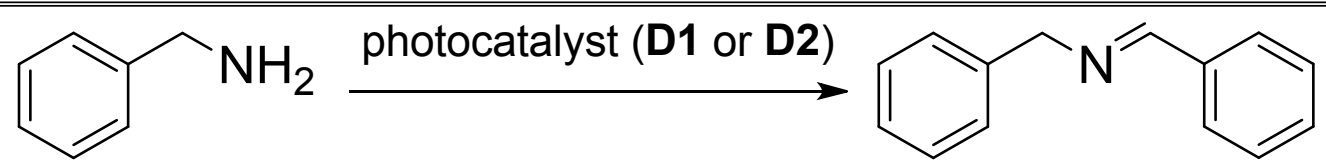

5

6

\begin{tabular}{llll}
\hline Entry & $\begin{array}{l}\text { Photocatalyst }^{\mathrm{a}} \\
\text { mol\%) }\end{array}$ & (type; $^{\text {Reaction time (hours) }}$ & Conversion $^{\mathrm{b}}$ (\%) \\
\hline 1 & D1; 0.5 & 1.5 & 52 \\
\hline 2 & D2; 0.5 & 1.5 & 78 \\
\hline 3 & D2; 0.5 & 2.0 & 83 \\
\hline 4 & D2; 1.0 & 3.0 & 87 \\
\hline 5 & D2; 1.5 & 3.0 & 94 \\
\hline 6 & D2; 2.0 & 3.0 & $>99^{\mathrm{c}}$ \\
\hline 7 & - & 3.0 & 0 \\
\hline $8^{\mathrm{d}}$ & D2; 2.0 & 3.0 & 0 \\
\hline $9^{\mathrm{e}}$ & D2; 2.0 & 3.0 & 47 \\
\hline $10^{\mathrm{f}}$ & D2; 2.0 & 3.0 & 34 \\
\hline $11^{\mathrm{g}}$ & D2; 2.0 & 3.0 & 20 \\
\hline
\end{tabular}

a Reaction conditions: benzylamine $(0.5 \mathrm{mmol}), \mathrm{CH}_{2} \mathrm{Cl}_{2}(5 \mathrm{~mL})$, room temperature, air, UV-LED irradiation (365 nm). ${ }^{b}$ Estimated with ${ }^{1} \mathrm{H}$ NMR. ${ }^{c}$ Quantitative isolated yield (also in the reaction scale of $1.5 \mathrm{mmol}$ ). ${ }^{\mathrm{d}}$ Reaction without using UV-LED irradiation. ${ }^{\mathrm{e}}$ Reaction in the presence of benzoquinone $(2.0 \mathrm{~mol} \%) .{ }^{\mathrm{f}}$ Reaction in the presence of DMPO (2.0 mol\%). ${ }^{g}$ Reaction in the presence of DABCO $(2.0 \mathrm{~mol} \%)$. 


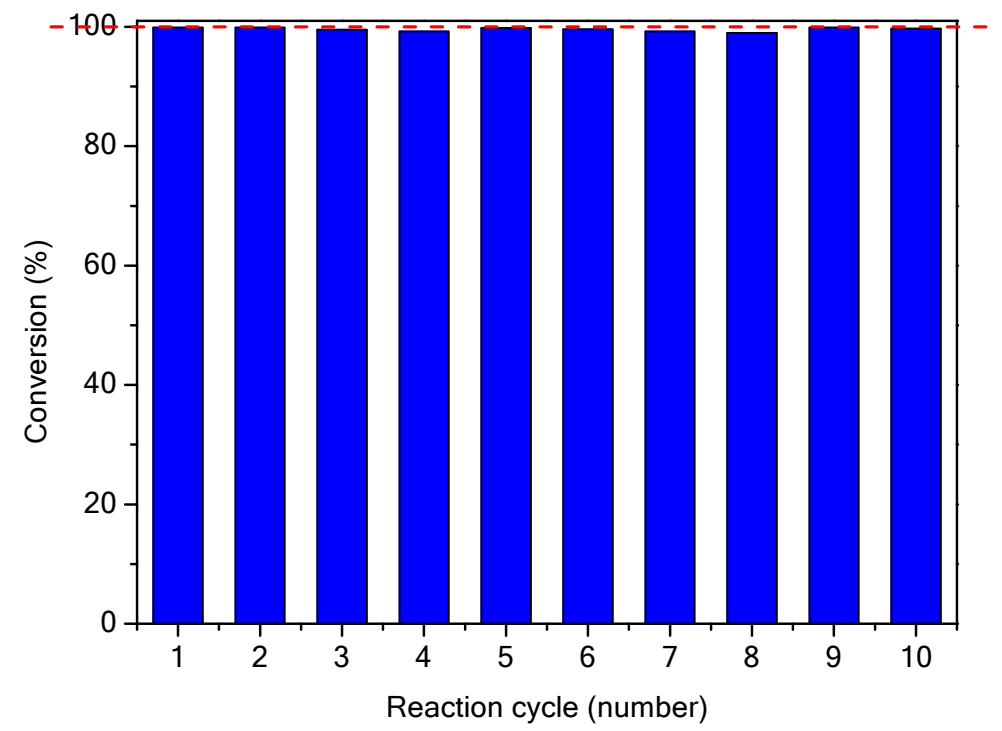

Figure S12. Data on the reusability studies with D2 toward the synthesis of $\mathrm{N}$ benzylidene benzylamine (6). 


\section{S3.2 Determination of conversion of benzylamine based on ${ }^{1} \mathrm{H} N M R$ spectra}

The calculations were based on the literature ${ }^{[2]}$ following reaction equation:

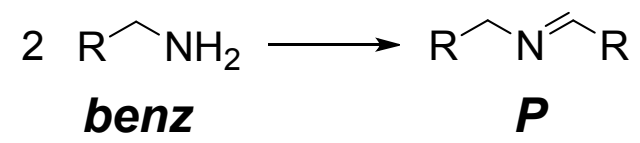

Conversion $(C)$ is defined as ratio of moles of benzylamine (benz) reacted $\left(n_{b e n z}^{R}\right)$ to the initial number of moles of benzylamine $\left(n_{\text {benz }}^{0}\right)$, i.e., $C=\frac{n_{\text {benz }}^{R}}{n_{\text {benz }}^{0}}$. Two moles of benzylamine (benz) react to provide one mole of product $(P ; N$-benzylidene benzylamine), i.e., $n_{\text {benz }}^{R}=2 n_{P}$ and $n_{\text {benz }}^{0}=2 n_{P}+n_{\text {benz }}$.

Considering the above equations, $C$ was estimated as follows:

$$
C=\frac{2 n_{P}}{2 n_{P}+n_{\text {benz }}}=\frac{2}{2+\frac{n_{\text {benz }}}{n_{P}}}
$$

Number of moles of benz $\left(n_{\text {benz }}\right)$ and $P\left(n_{P}\right)$ were calculated as follows:

$$
n_{\text {benz }}=\frac{\text { integral of benz }}{N_{\text {benz }}} \text { and } n_{P}=\frac{\text { integral of } P}{N_{P}}
$$

where $N_{\text {benz }}$ and $N_{P}$ stand for the number of protons represented by the given peak. 
S3.3 ${ }^{1} \mathrm{H}$ NMR spectrum of the isolated N-benzylidene benzylamine (6) under optimized conditions
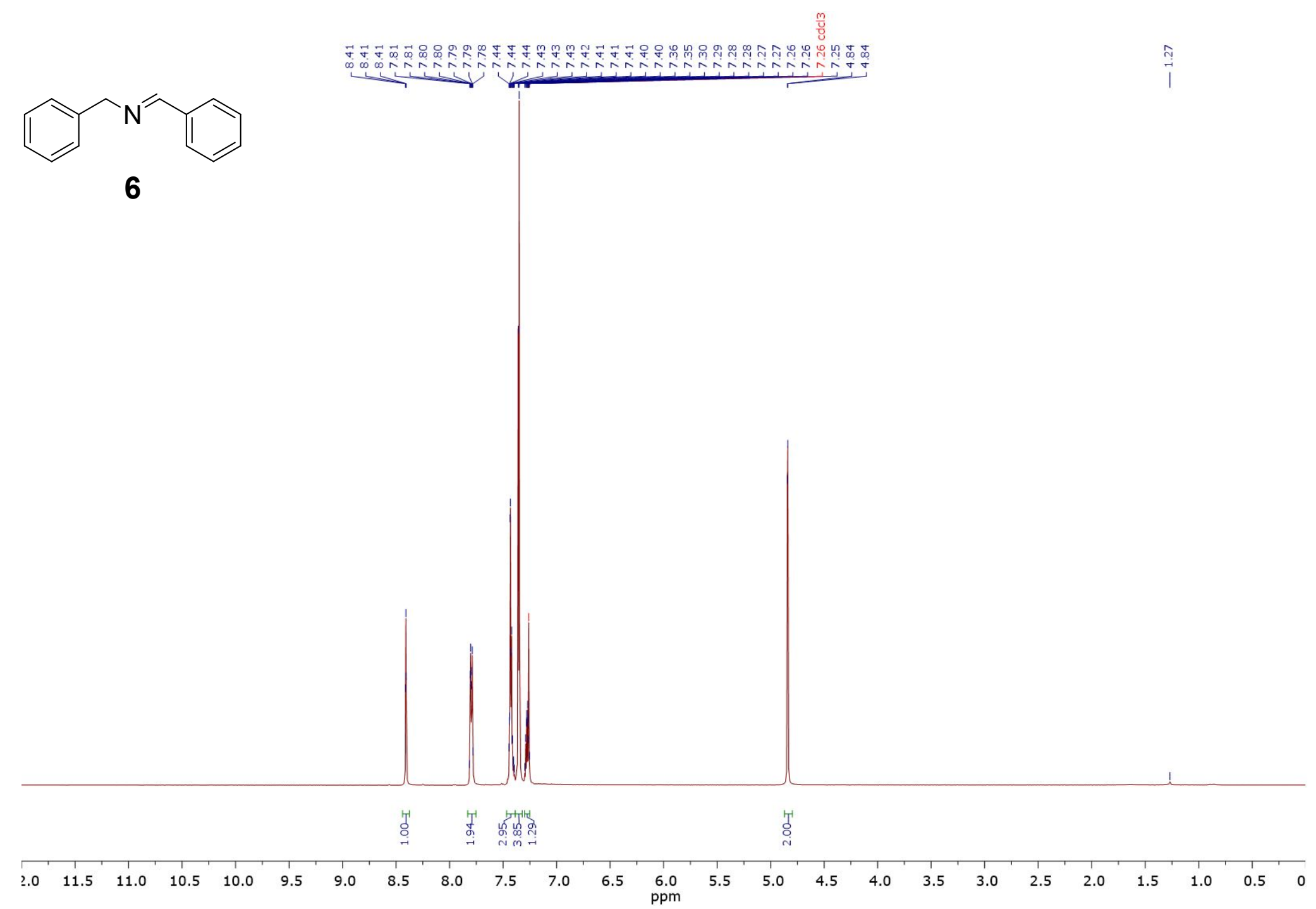

Figure S13. ${ }^{1} \mathrm{H}$ NMR spectrum $\left(500 \mathrm{MHz}, \mathrm{CDCl}_{3}\right)$ of isolated $\mathrm{N}$-benzylidene benzylamine (6) from the photocatalytic reaction. 


\section{S34.4 Determination of HOMO-LUMO band gaps for D1 and D2}

Tauc plot toward HOMO-LUMO band gap energy determination ${ }^{[3]}$ for D1 and D2 are presented in Figure S14 and Figure S15.

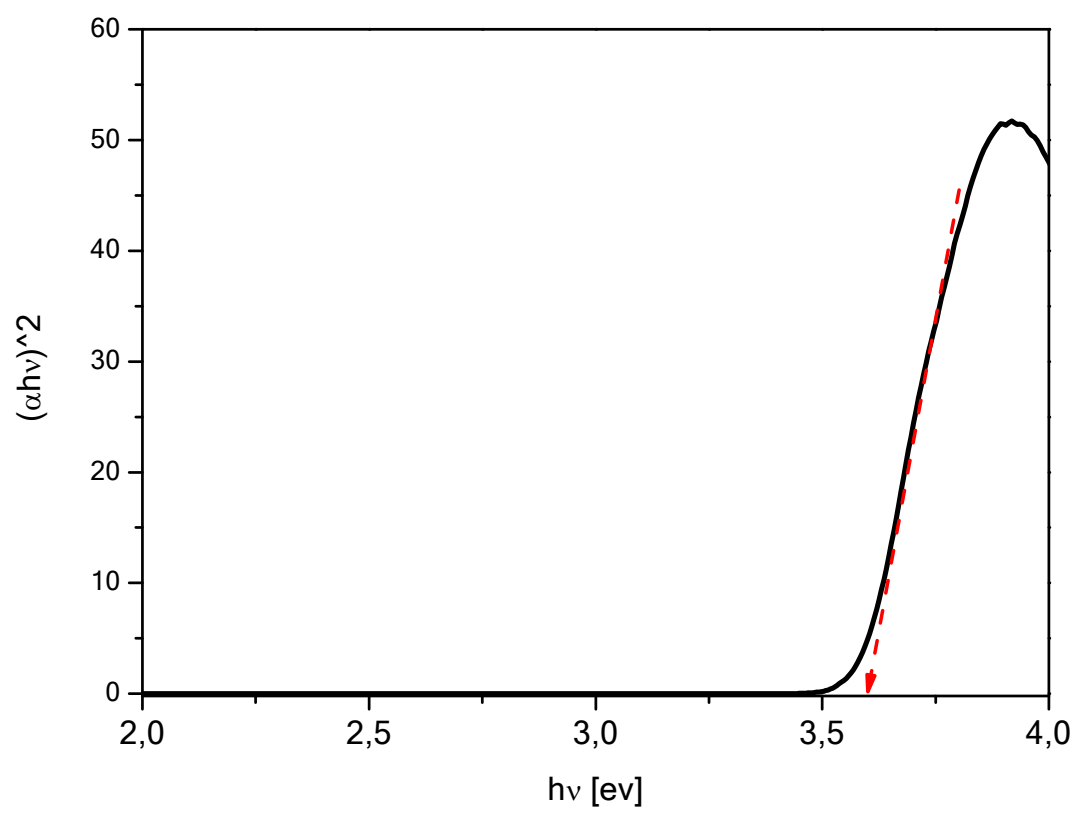

Figure S14. Tauc plot for D1. The linear part of the plot is extrapolated to the $x$-axis.

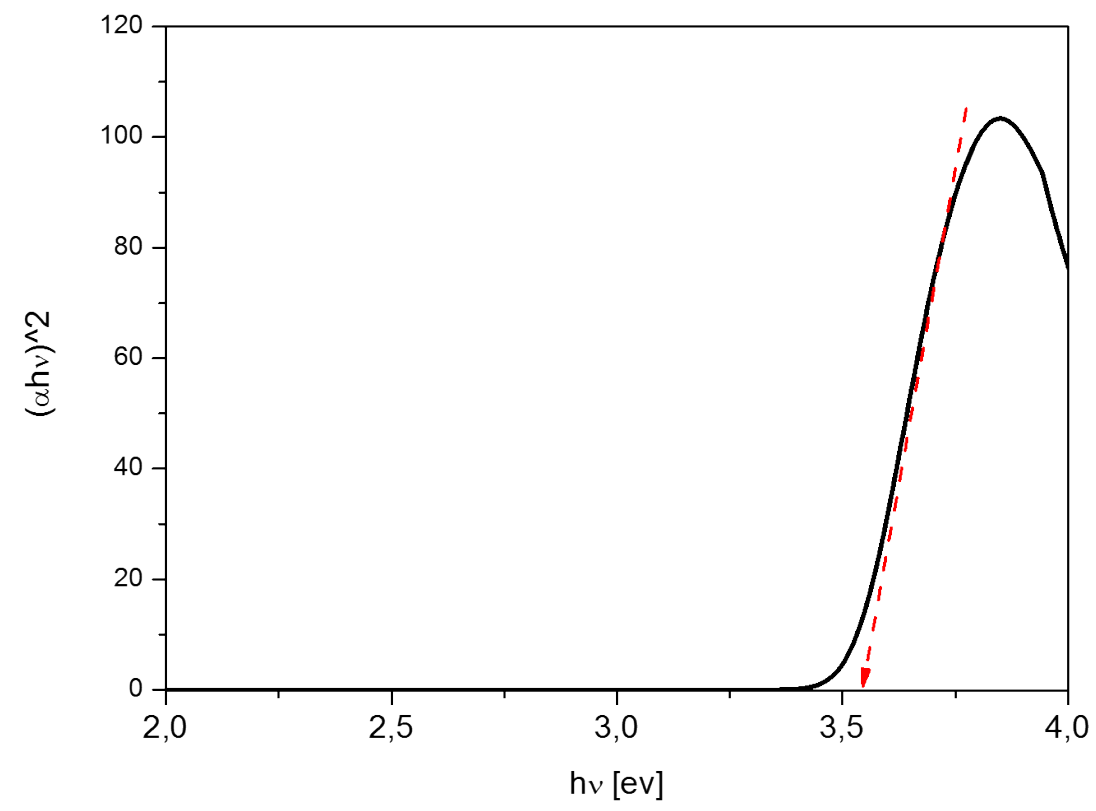

Figure S15. Tauc plot for D2. The linear part of the plot is extrapolated to the $x$-axis.

\section{S3.5 Plausible literature reaction mechanism}

The plausible reaction mechanism of the studied photocatalytic reaction ${ }^{[1]}$ is presented in Figure S16. 


$$
\begin{aligned}
& \text { light irradiation } \\
& \text { D2 } \stackrel{(365 \mathrm{~nm})}{\longrightarrow} \text { D2 }\left(\mathrm{h}^{+}, \mathrm{e}^{-}\right) \\
& \mathrm{O}_{2}+\mathrm{e}^{-} \longrightarrow \overline{\mathrm{O}}_{2}
\end{aligned}
$$

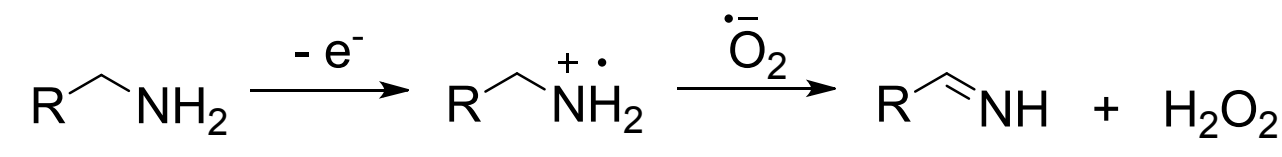<smiles>[R]C=NC[R]</smiles>

Figure S16. Plausible literature reaction mechanism for the studied photocatalytic coupling (D2 was included as the representative photocatalyst).

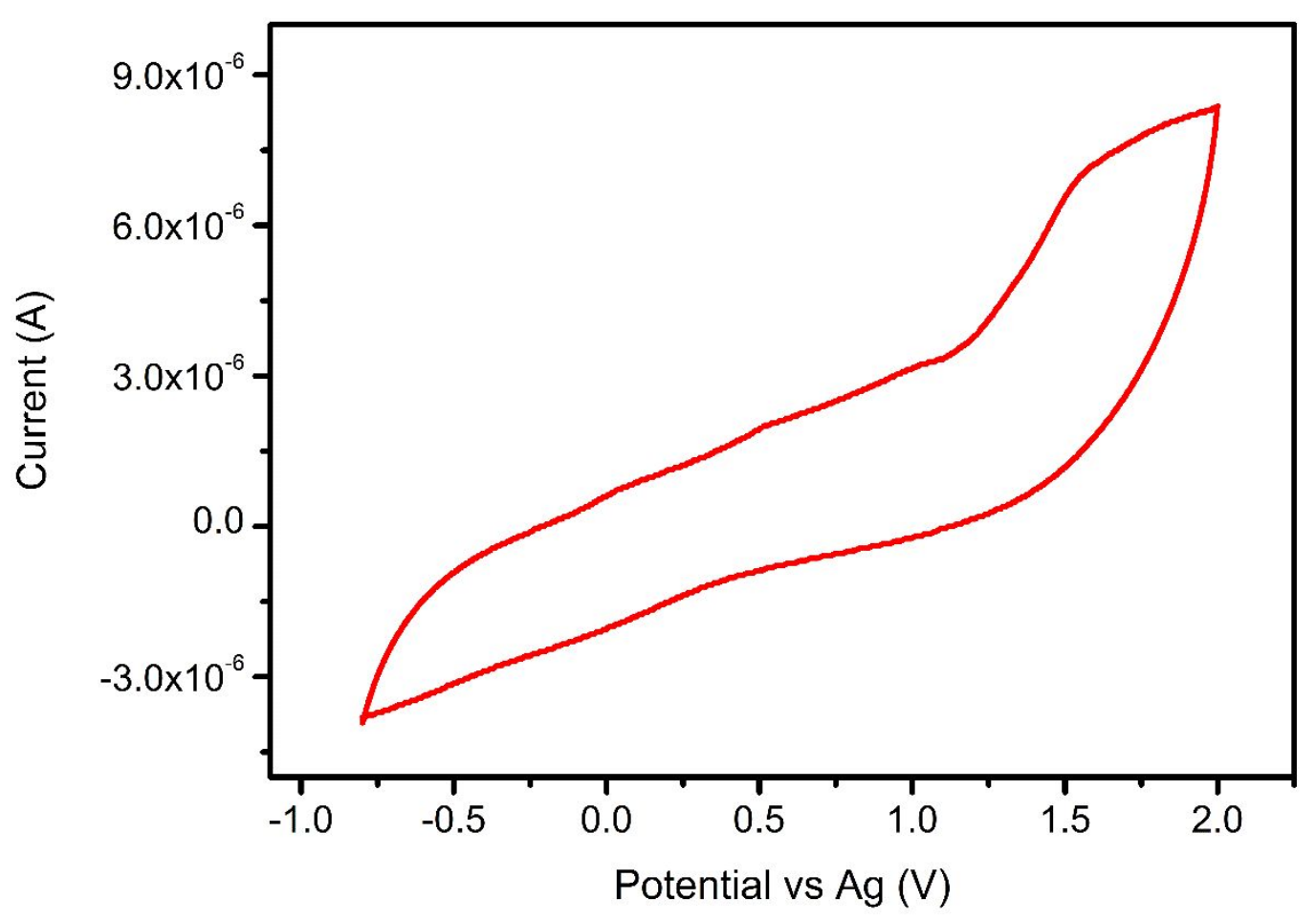

Figure S17. Cyclic voltammogram for D1. 


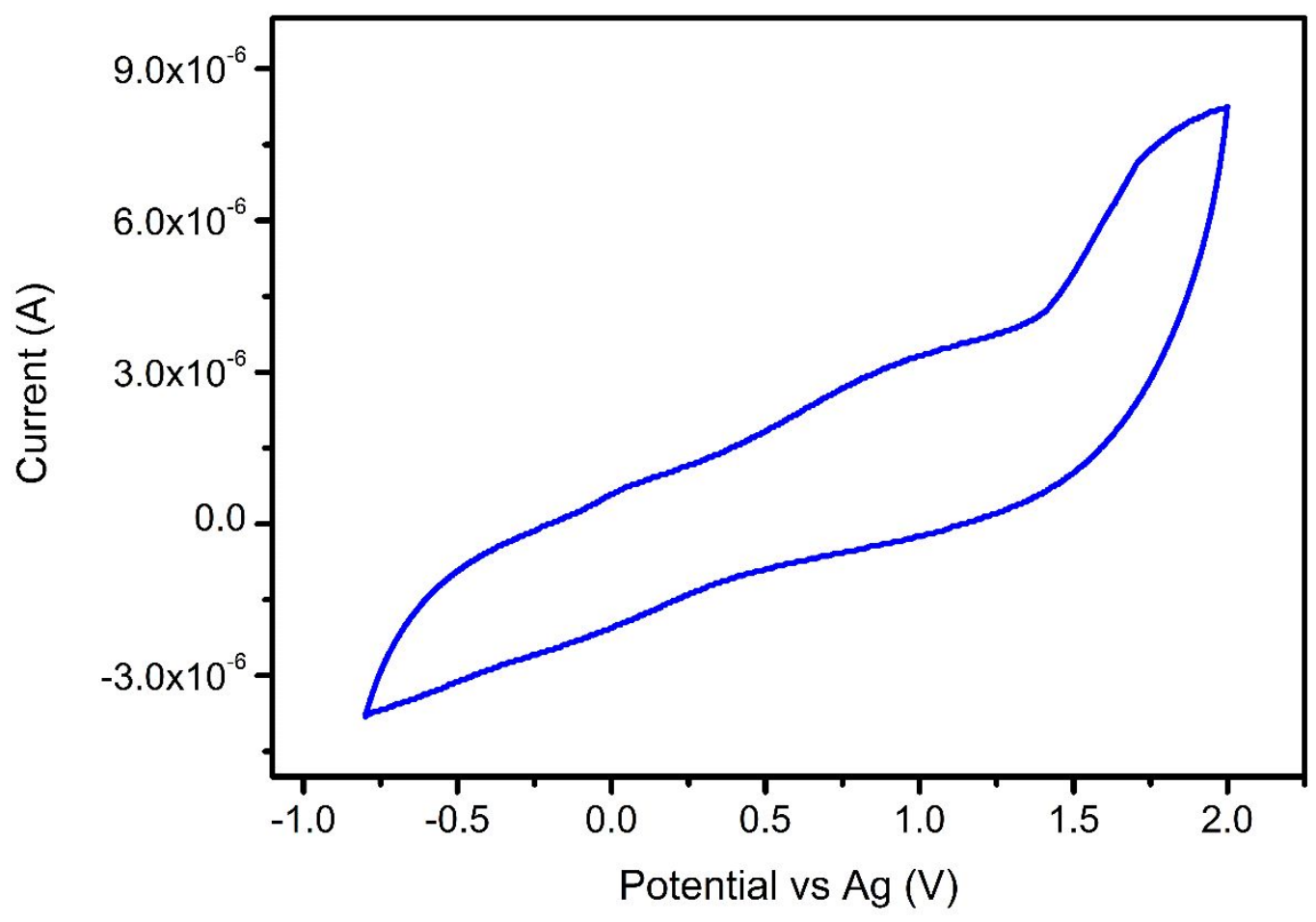

Figure S18. Cyclic voltammogram for D2.

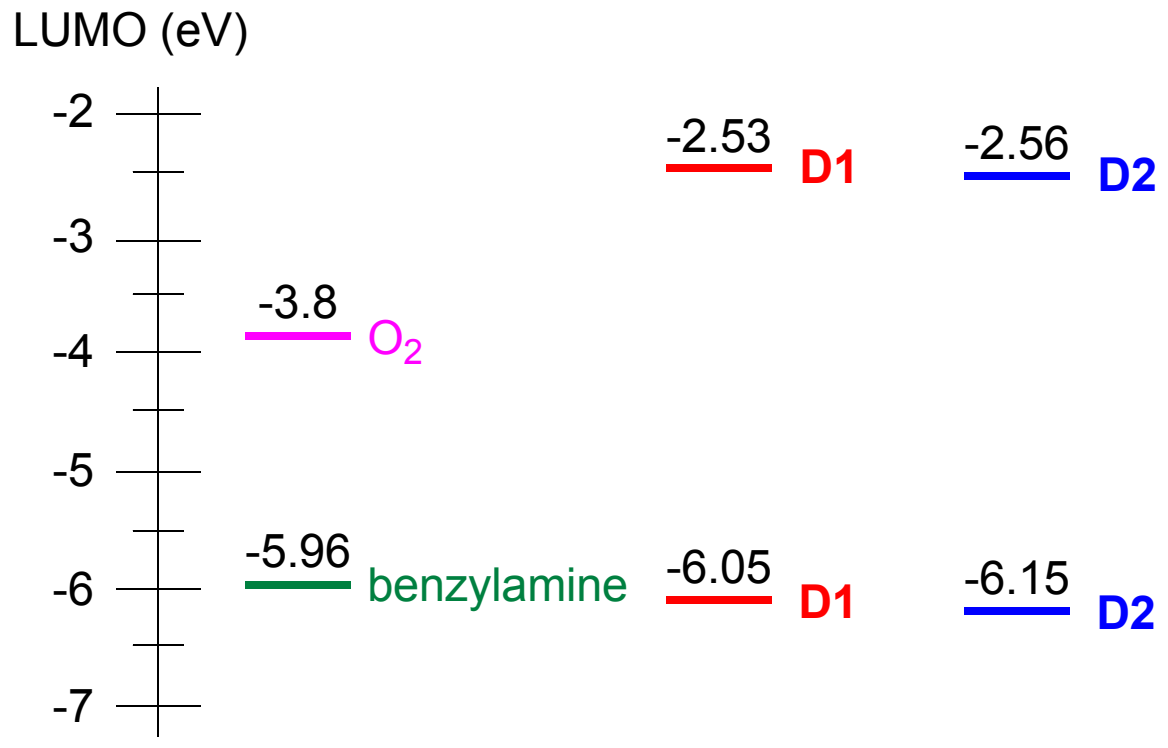

$\mathrm{HOMO}(\mathrm{eV})$

Figure S19. Schematic representation of the HOMO/LUMO energy levels of D1 and D2. HOMO $(\mathrm{eV})$ and LUMO $(\mathrm{eV})$ values for $\mathbf{D} 1$ and $\mathbf{D} 2$ were calculated as follows ${ }^{[2]}$ : $\mathrm{HOMO}=-\left[E_{0 \mathrm{x}}^{\mathrm{onset}}+4.8\right] \mathrm{eV}$, where $E_{\mathrm{ox}}^{\mathrm{onset}}$ was calculated from the cyclic voltammetry measurements, $\mathrm{LUMO}=-\left[\mathrm{HOMO}+E_{\mathrm{eg}}^{\mathrm{opt}}\right]$, where $E_{\mathrm{eg}}^{\mathrm{opt}}$ was calculated the absorption onset. Please note that these band gaps and the respective values calculated from the Tauc plot method (Figures S14, S15) were highly consistent. 


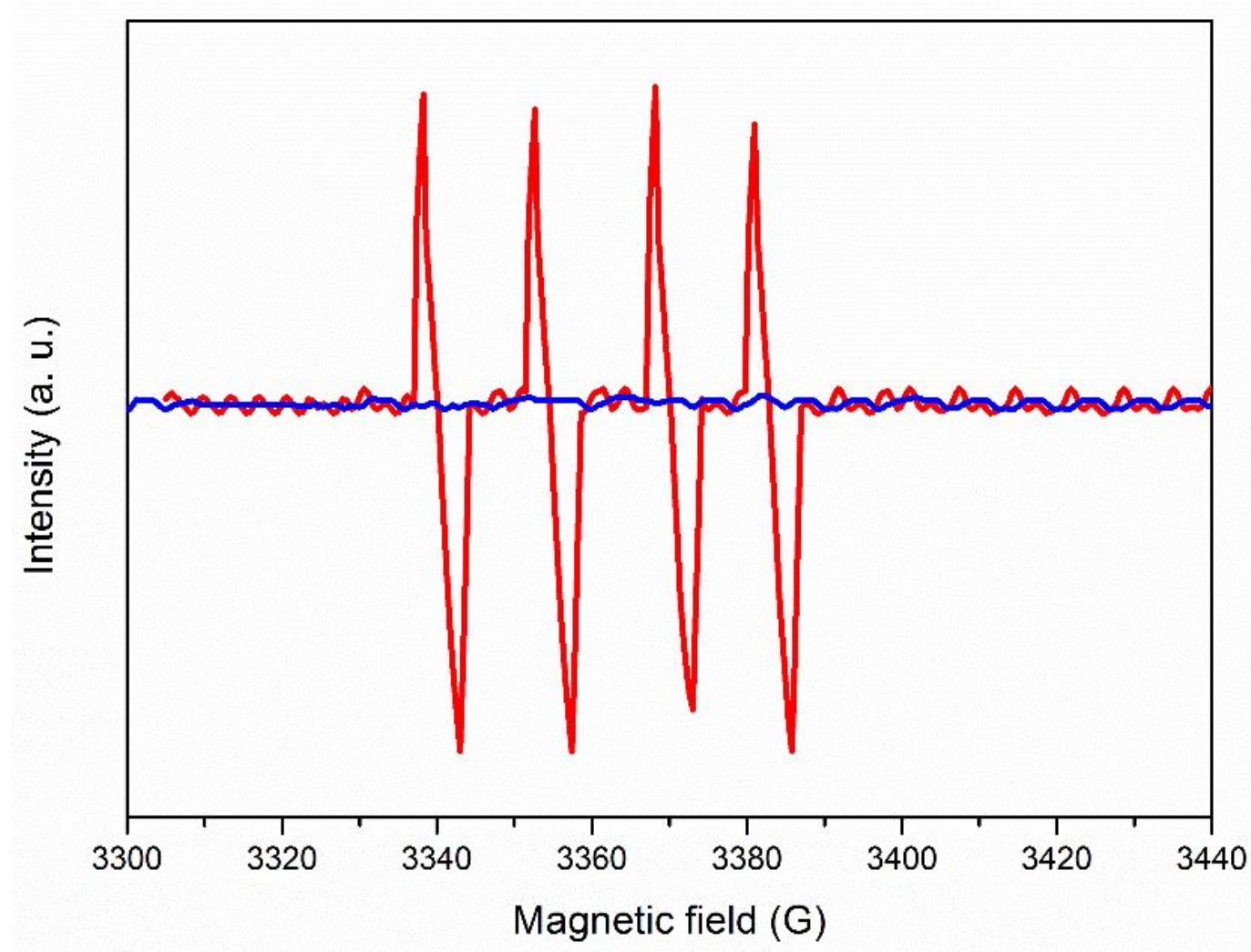

Figure S20. EPR spectra of DMPO- $\mathrm{O}_{2}{ }^{\bullet-}$. The spectrum was measured at room temperature with irradiation (red line) or without irradiation (blue line).

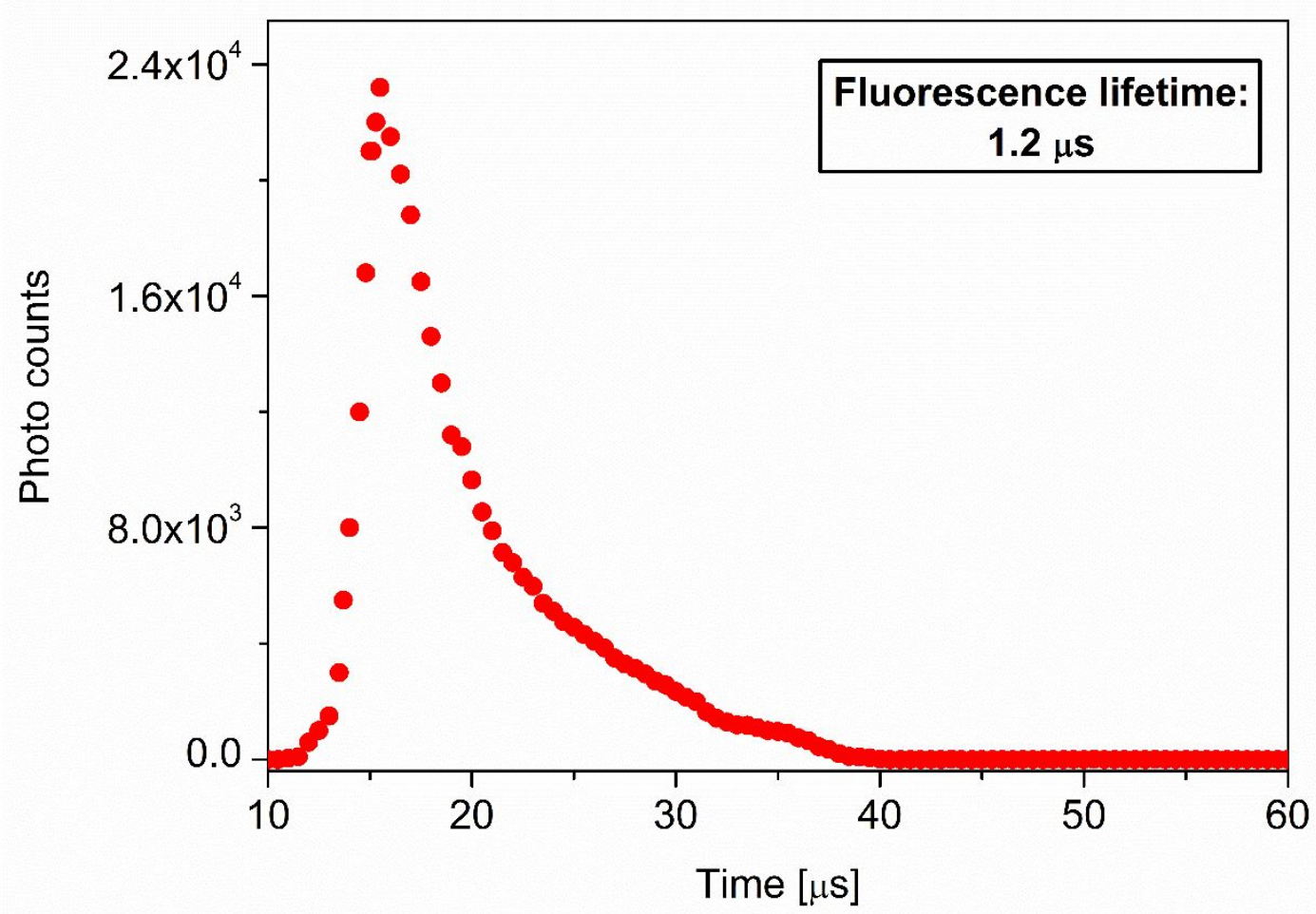

Figure S21. Fluorescence lifetime curve for D1. The fluorescence lifetime parameter is presented in the figure. 


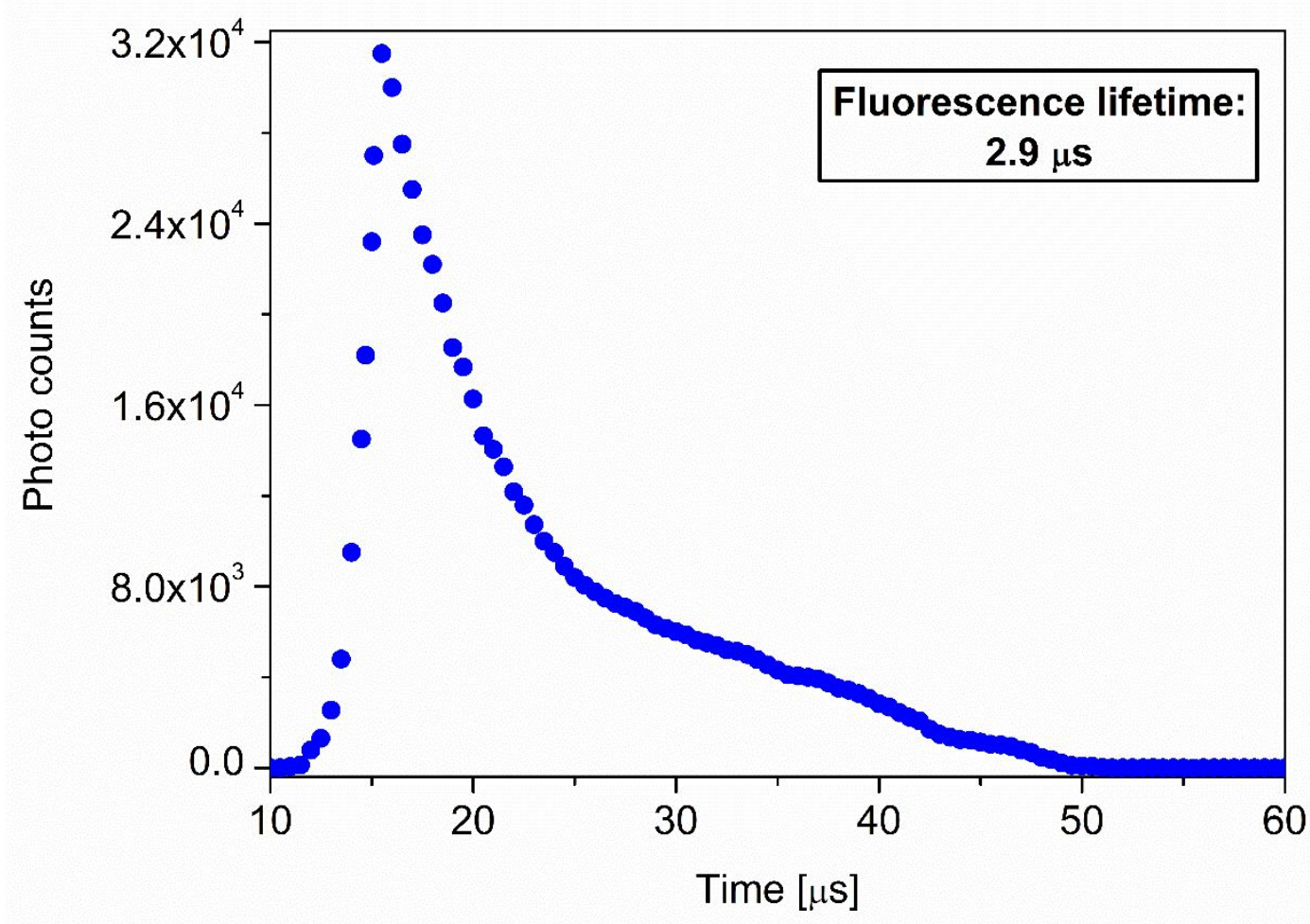

Figure S22. Fluorescence lifetime curve for D2. The fluorescence lifetime parameter is presented in the figure. 
S4. TGA curves for D1 and D2

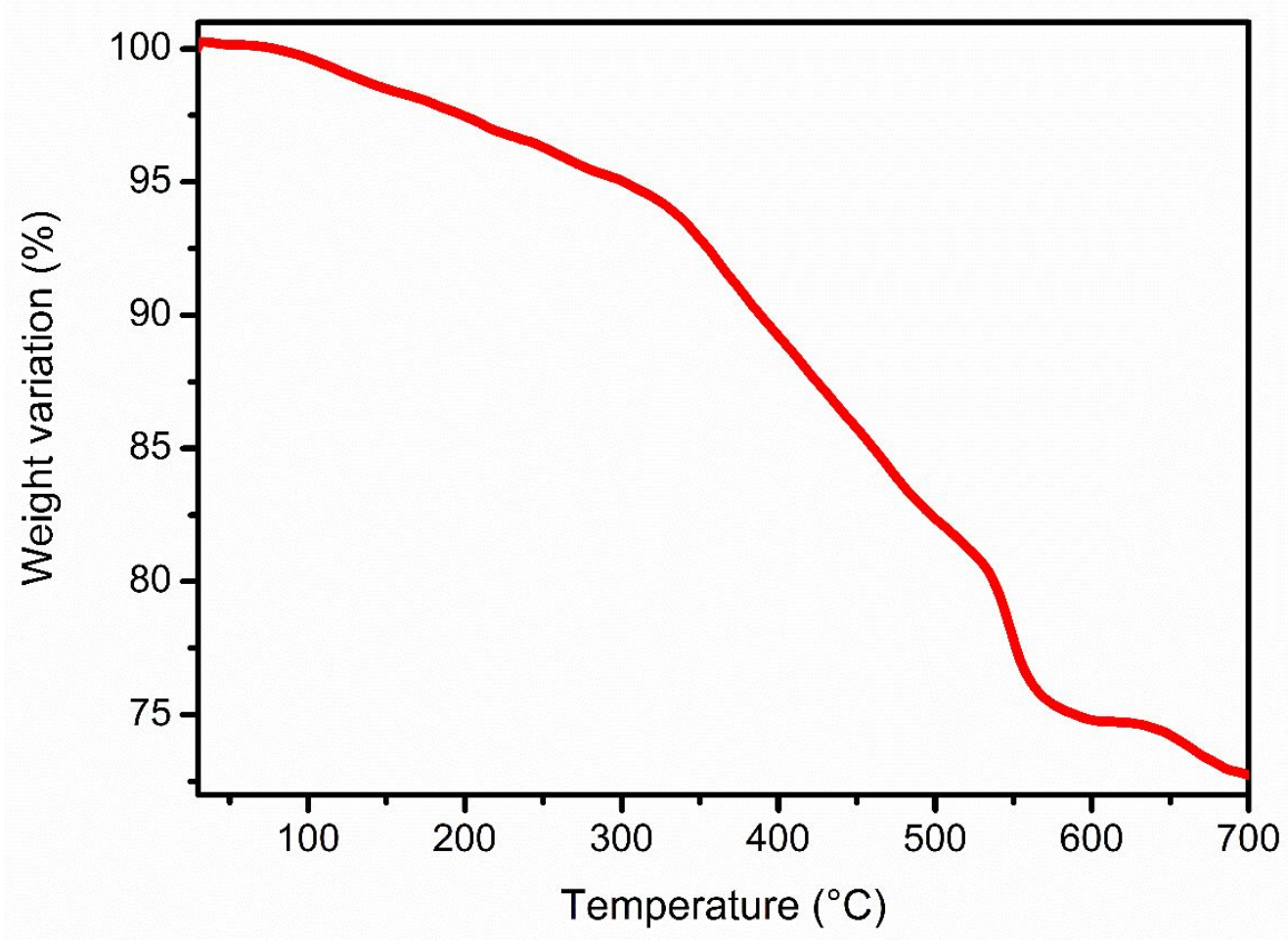

Figure S23. TGA curve (in argon) for D1.

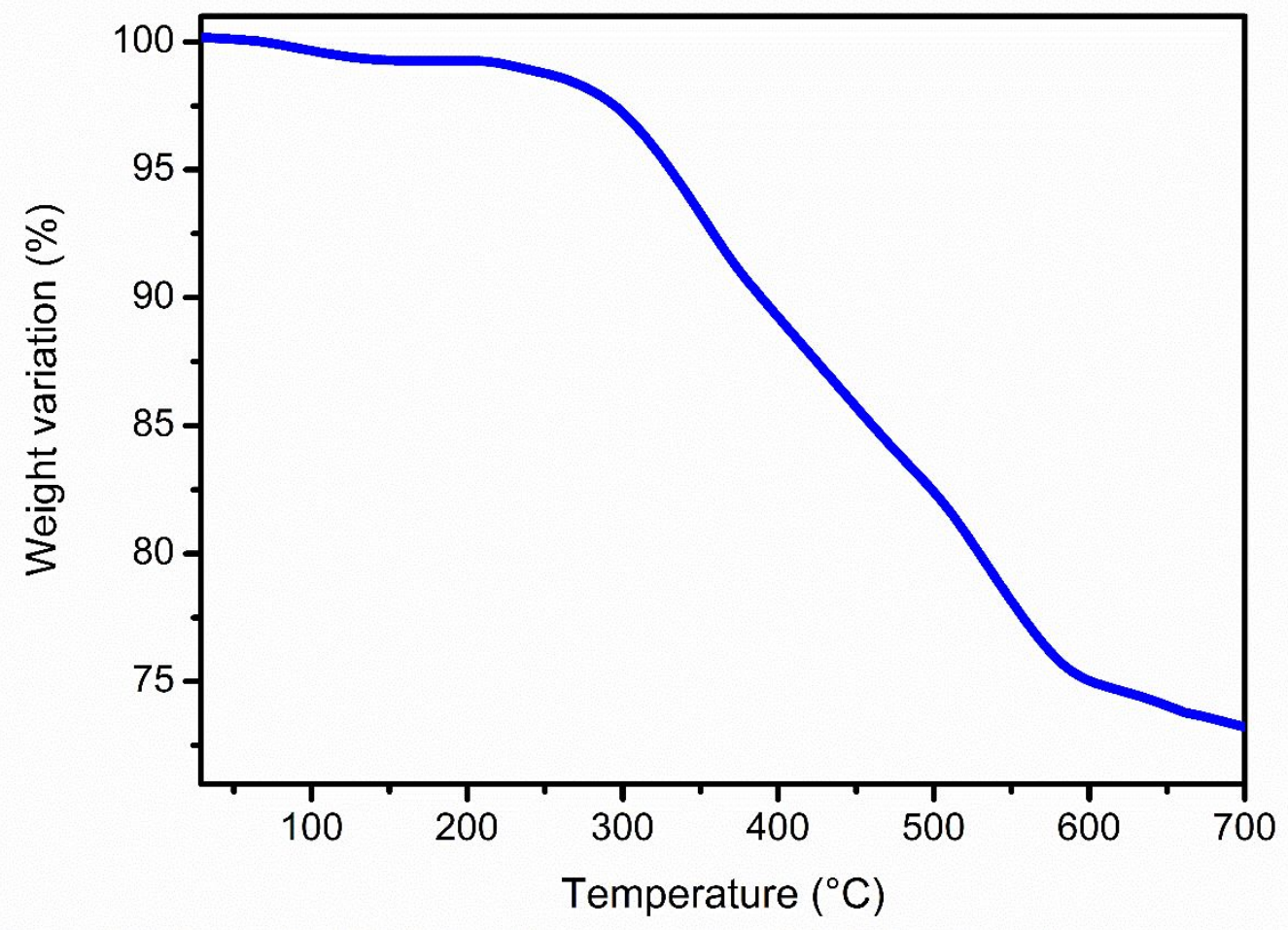

Figure S24. TGA curve (in argon) for D2. 


\section{S5. UV-Vis spectra}
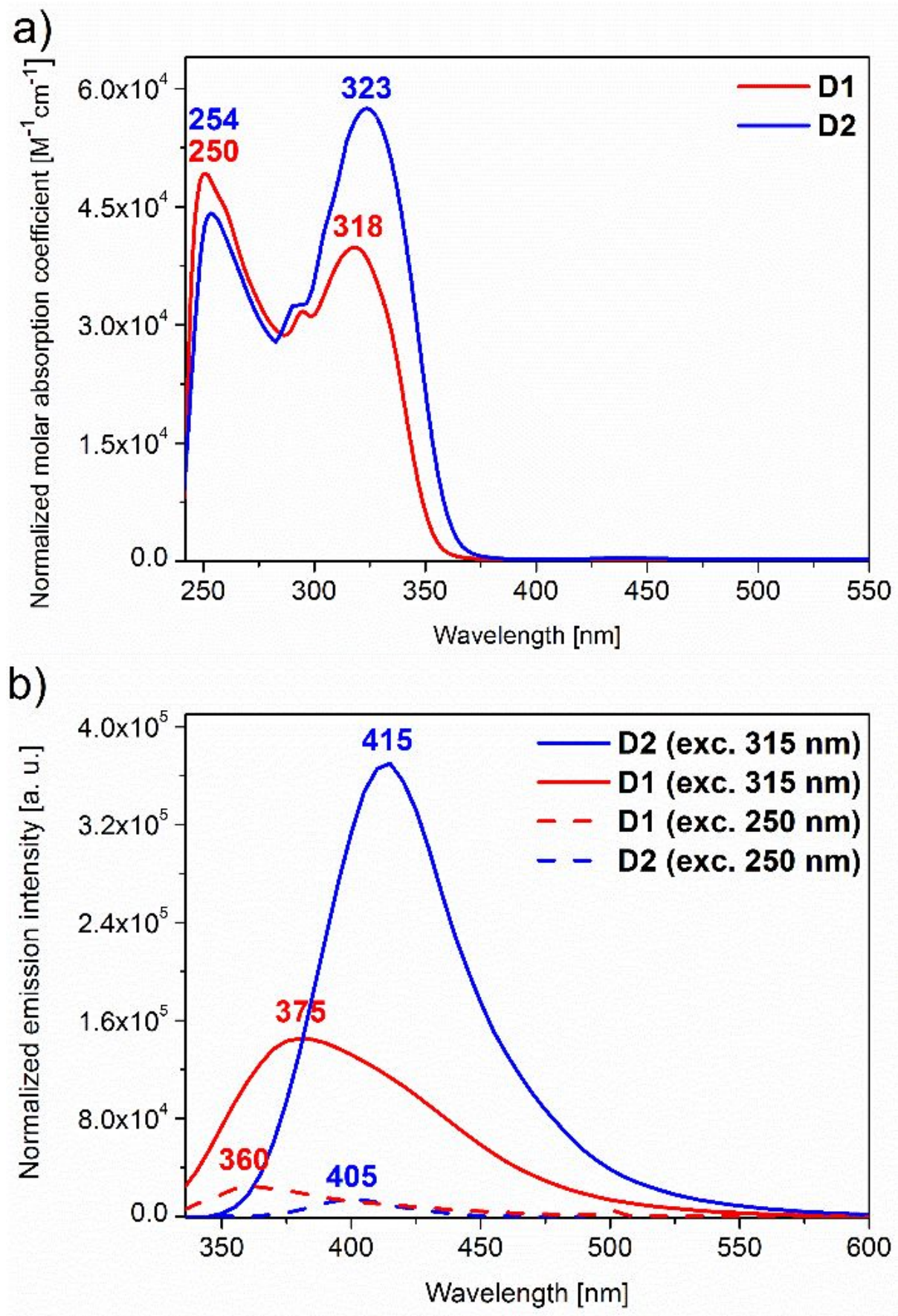

Figure S25. (a) UV-Vis and (b) emission spectra for D1 and D2. Concentrations of the samples: $2 \cdot 10^{-5} \mathrm{M}\left(\mathrm{CHCl}_{3}\right)$. 


\section{S6. OLED application trials with D1 and D2}

The construction of the devices was based on the previously reported protocol[4] with slight modifications. Clean indium tin oxide (ITO) was died in $130^{\circ} \mathrm{C}$ for $20 \mathrm{~min}$ and then treated with UV-Ozone for 7 minutes. Then, a layer of poly $(3,4-$ ethylnenedioxythiophene):poly(styrenesulfonate) (PEDOT:PSS) was prepared by spin coating onto the ITO at $700 \mathrm{rpm}$ for 10 seconds and $3500 \mathrm{rpm}$ for 90 seconds. It was then heated at $130^{\circ} \mathrm{C}$ for 40 minutes. In the meantime, an excess of a $\mathrm{CHCl}_{3}$ solution of D1 or D2 (7 mg. $\left.\mathrm{mL}^{-1}\right)$ was added to the stock solution of 9,9'-(1,3-phenylene)-bis$9 \mathrm{H}$-carbazole (MCP) in $\mathrm{CHCl}_{3}$ to the final concentration of $25 \mathrm{wt} \%$. This solution was spincoated on the ITO/PEDOT:PSS later and the as-obtained samples were placed into a deposition chamber. Tri[(3-pyridyl)-phen-3-yl]benzene (TmPyPb), LiF and Al were deposited thermally $\left(2 \cdot 10^{5} \mathrm{mbar}\right)$. The emission area of the devices equaled to 0.15-0.16 $\mathrm{cm}^{2}$. OLED device comprising D1 was labeled as 'OLED-D1', whilst the respective device consisting of D2 was labelled as 'OLED-D2'. It was found that OLEDD1 emission maximum was placed at $380 \mathrm{~nm}$, whilst for OLED-D2 this value equaled to $410 \mathrm{~nm}$.

Luminescence-voltage (L-V) and current density-voltage (J-V) curves for device OLED-D1 and OLED-D2 are presented in Figure S26.

Summary of selected working parameters of the constructed OLEDs together with the comparison with the other literature examples of OLEDs comprising aromatic dendrimers are presented in Table S4. 

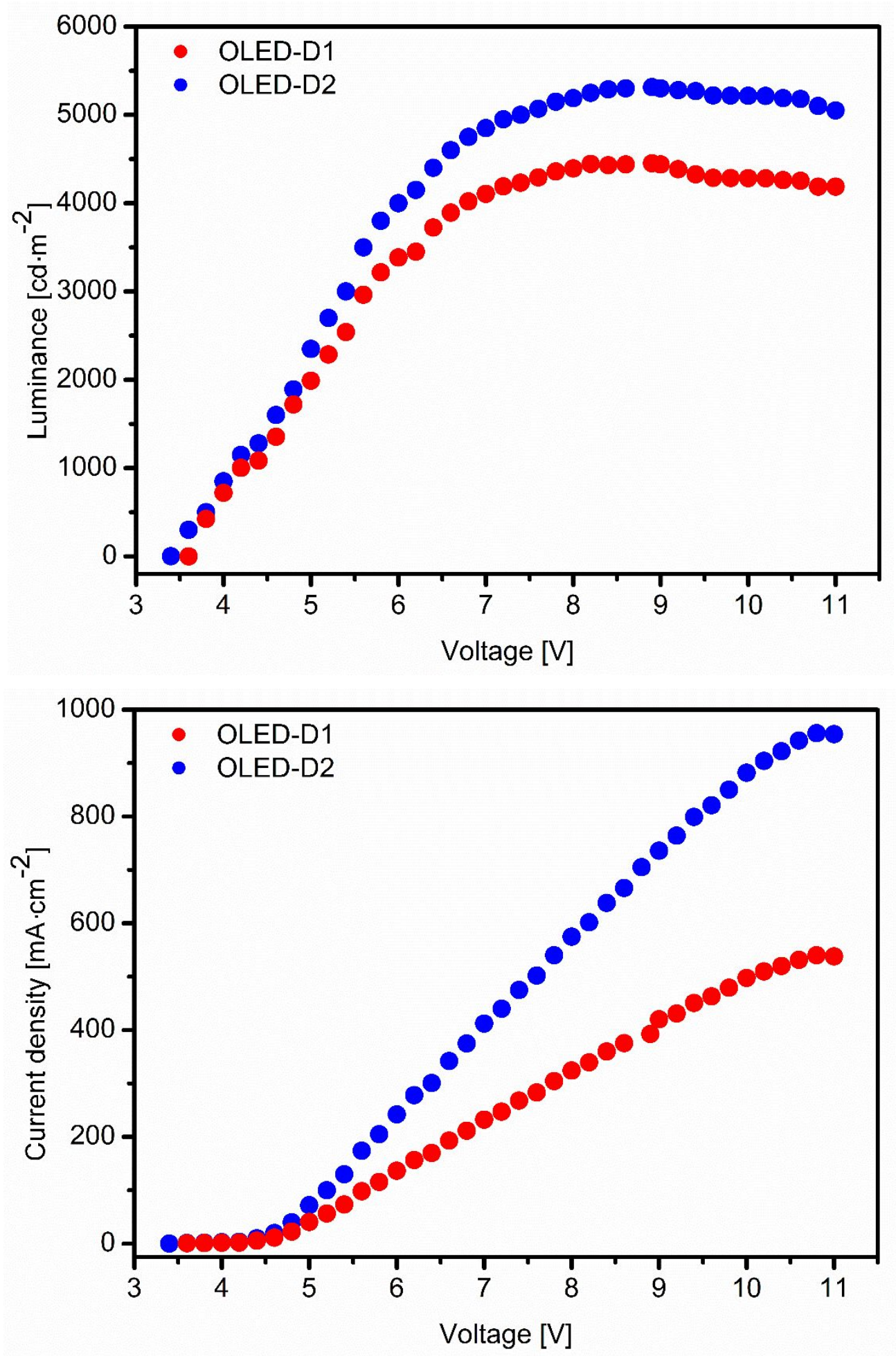

Figure S26. Luminescence-voltage (L-V) (top) and current density-voltage (J-V) (bottom) profiles for device OLED-D1 (red) and OLED-D2 (blue). 
Table S4. Summary of selected working parameters of the constructed OLEDs together with the comparison with the other literature examples of OLEDs comprising aromatic dendrimers.

\begin{tabular}{|c|c|c|c|c|c|}
\hline Device & $\begin{array}{l}\text { Emmision } \\
\text { maximum } \\
{[\mathrm{nm}]}\end{array}$ & $\begin{array}{l}\text { Maximum } \\
\text { external } \\
\text { quantum } \\
\text { efficiency } \\
{[\%]} \\
\end{array}$ & $\begin{array}{l}\text { Turn-on- } \\
\text { voltage } \\
\text { [V] }\end{array}$ & $\begin{array}{l}\text { Maximum } \\
\text { luminance } \\
{\left[\mathrm{cd} \cdot \mathrm{m}^{-2}\right]}\end{array}$ & Ref. \\
\hline OLED-D1 & 380 & 0.85 & 3.6 & 4302 & $\begin{array}{l}\text { This } \\
\text { work }\end{array}$ \\
\hline OLED-D2 & 410 & 2.82 & 3.4 & 5585 & $\begin{array}{l}\text { This } \\
\text { work }\end{array}$ \\
\hline \multicolumn{6}{|c|}{ Literature examples of other OLED devices comprising an aromatic dendrimer } \\
\hline Compound & $\begin{array}{l}\text { Emmision } \\
\text { maximum } \\
{[\mathrm{nm}]}\end{array}$ & $\begin{array}{l}\text { Maximum } \\
\text { external } \\
\text { quantum } \\
\text { efficiency } \\
{[\%]}\end{array}$ & $\begin{array}{l}\text { Turn-on- } \\
\text { voltage } \\
\text { [V] }\end{array}$ & $\begin{array}{l}\text { Maximum } \\
\text { luminance } \\
{\left[\mathrm{cd} \cdot \mathrm{m}^{-2}\right]}\end{array}$ & Ref. \\
\hline $\begin{array}{l}\text { Pyrene-containing } \\
\text { 1,3,5-triazine } \\
\text { based dendrimers }\end{array}$ & $451-460$ & 0.97 & 3.5 & $1273-4306$ & [4] \\
\hline $\begin{array}{l}\text { Phenoxazine- } \\
\text { containing } 1,3,5- \\
\text { triazine based } \\
\text { dendrimers }\end{array}$ & $520-580$ & Not given & Not given & Not given & [5] \\
\hline $\begin{array}{l}\text { Carbazole- } \\
\text { containing 1,3,5- } \\
\text { triazine based } \\
\text { dendrimers }\end{array}$ & $546-552$ & $1.2-6.5$ & $2.4-2.7$ & $7942-25085$ & [6] \\
\hline $\begin{array}{l}\text { Carbazole- } \\
\text { containing 1,3,5- } \\
\text { triazine based } \\
\text { dendrimers }\end{array}$ & $500-550$ & $2.8-20.6$ & $3.0-3.2$ & $1441-8963$ & [7] \\
\hline $\begin{array}{l}\text { Fluorene- } \\
\text { containing 1,3,5- } \\
\text { triazine based } \\
\text { dendrimers }\end{array}$ & $436-460$ & $0.83-0.99$ & $3.0-3.5$ & $1610-3093$ & [8] \\
\hline
\end{tabular}




\section{S7. References}

[1] Su, F.; Mathew, S. C.; Mohlmann, L.; Antonietti, M.; Wang, X.; Blechert, S. Aerobic Oxidative Coupling of Amines by Carbon Nitride Photocatalysis with Visible Light. Angew. Chem. Int. Ed. 2011, 50, 657-660.

[2] Bohra, H.; Li, P.; Yang, C.; Zhao, Y.; Wang, M. "Greener" and modular synthesis of triazine-based conjugated porous polymers via direct arylation polymerization: structure-function relationship and photocatalytic application. Polym. Chem. 2018, 9, 1972-1982.

[3] Makuła, P.; Pacia, M.; Macyk, W. How To Correctly Determine the Band Gap Energy of Modified Semiconductor Photocatalysts Based on UV-Vis Spectra. J. Phys. Chem. Lett. 2018, 9, 6814-6817.

[4] Li, Y. F.; Xie, X.; Gong, H. J.; Liu, M. L.; Chen, R. F.; Gao, D. Q.; Huang, W. Two bipolar blue-emitting fluorescent materials based on 1,3,5-trizine and peripheral pyrene for light-emitting diodes. Dyes Pigm. 2017, 145, 43-53.

[5] Tanaka, H.; Shizu, K.; Nakanotani, H.; Adachi, C. Twisted intramo-lecular charge transfer state for long-wavelengh thermally acti-vated delayed fluorescence. Chem. Mater. 2013, 25, 3766-3771.

[6] Sun, K.; Sun, Y.; Huang, T.; Luo, J.; Jiang, W.; Sun, Y. Design strategy of yellow thermally activated delayed fluorescent dendrimers and their highly efficient non-doped solution-processed OLEDs with low driving voltage. Org. Electron. 2017, 42, 123-130.

[7] Ma, Z.; Wan, Y.; Dong, W.; Si, Z.; Duan, Q.; Shao, S. Alkoxy encapsula-tion of carbazole-based thermally activated delayed fluorescent dendrimers for highly efficient solution-processed organic light emitting diodes. Chin. Chem. Lett. 2021, 32, 703-707.

[8] Ren, S.; Zeng, D.; Zhong, H.; Wang, Y.; Qian, S.; Fang, Q. Star-Shaped DonorT-Acceptor Conjugated Oligomers with 1,3,5-Triazine Cores: Convergent Synthesis and Multifunctional Properties. J. Phys. Chem. B 2010, 114, 1037410383. 